\title{
Atlantic Ocean Circulation as the Driving Force for the Holocene Thermal Maximum and Millennial Scale Climatic Variability
}

\author{
Kari Hänninen \\ Department of Biological and Environmental Sciences, University of Jyväskylä, Finland \\ Received September 14, 2021; Revised November 26, 2021; Accepted December 13, 2021
}

\section{Cite This Paper in the following Citation Styles}

(a): [1] Kari Hänninen, "Atlantic Ocean Circulation as the Driving Force for the Holocene Thermal Maximum and Millennial Scale Climatic Variability," Environment and Ecology Research, Vol. 9, No. 6, pp. 370 - 388, 2021. DOI: 10.13189/eer.2021.090605.

(b): Kari Hänninen (2021). Atlantic Ocean Circulation as the Driving Force for the Holocene Thermal Maximum and Millennial Scale Climatic Variability. Environment and Ecology Research, 9(6), 370 - 388. DOI: 10.13189/eer.2021.090605.

Copyright $\odot 2021$ by authors, all rights reserved. Authors agree that this article remains permanently open access under the terms of the Creative Commons Attribution License 4.0 International License

\begin{abstract}
The aim of this meta-study is to provide an understanding of the Atlantic Ocean Circulation as the driving force for the Holocene Thermal Maximum (HTM) and Millennial Scale Climatic Variability. In addition to continental ice sheets, during the Great Ice Age (GIA) there was also a 900-m thick floating ice shelf (FIS) in the Arctic Ocean. Below the FIS, it was likely freshwater. It is plausible that around 11,700 BP the Gulf Stream established the present flow route. Until around 10,800 BP the Grand Banks of Newfoundland (GBN) diverted part of the Gulf Stream flow west towards the north-eastern American coast, where the HTM existed between ca. 11,600 and 10,800 BP. Soon after the Gulf Stream was able to flow over the GBN, the HTM started in Ireland ca. 10,700 BP. By ca. 10,000 BP, the Gulf Stream arrived on the coast of Norway, which diverted the outflow south through the English Channel for approximately 2,000 years. In Northern and Central Europe, the HTM existed between ca. 9,500 and 7,000 BP. Due to the melting of ice, the outflow turned brackish, and was mainly surface currents, having a temperature of around $0^{\circ} \mathrm{C}$. The formation of descending salty water (DSW), which creates the suction of the Gulf Stream, was low. Between ca. 6,000 and 4,500 BP, there was Mid-Holocene cooling. Then the Arctic Ocean water was salinated by double diffusive convection (DDC). When DSW formation increased to its present-day volume, the Neoglacial period started ca. 4,500 BP. Since then, outflow has taken place mainly through cold
\end{abstract}

(approximately $-2^{\circ} \mathrm{C}$ ) undercurrents. At this time, the intensive millennial scale cycling of warmer and colder periods also started. When increasingly larger areas in Arctic Ocean are covered by insulating multi-year ice (MYI), DSW formation and the suction of the Gulf Stream decrease, and vice versa. The amplitude of the cycle is approximately 750 to 800 years.

Keywords Route Change of the Gulf Stream, Onset of Holocene, Holocene Thermal Maximum, Mid-Holocene Cooling, Neoglacial Period, Floating Ice Shelf, Descending Salty Water, Long-Term Changes in the Flow of the Gulf Stream, Development of the Arctic Ocean Undercurrents

\section{Introduction}

The Holocene is the current geological epoch, a continuation of the Pleistocene. The onset of the Holocene is marked by an abrupt rise in temperature of 5 to $8^{\circ} \mathrm{C}$ from what it was during the Great Ice Age (GIA). In southern Greenland temperature rose by $7^{\circ} \mathrm{C}$ ca. $11,650 \mathrm{BP}$ [1]. In northern England, a rise of $8^{\circ} \mathrm{C}$ was observed ca. 11,550 BP [2] and along the coast of Norway a rise of $5.0^{\circ} \mathrm{C}$ took place ca. 11,500 BP [3]. Sea level rise was first detected in the Carioca Basin ca. 11,500 BP [4]. 
During the first half of the Holocene, there were periods during which the coherent warming exceeded the present-day temperature by as much as several degrees of centigrade. Those time intervals are called the Holocene Thermal Maximum (HTM).

Maximum of hazel (Corylus avellana) occurred in the Aran Islands, Ireland ca. 10,700 BP [5]. The HTM there also started at that time. In central England, there was a sharp increase in annual average air temperatures between ca. 10,000 and 7,000 BP [6]. The Jostedalsbreen maritime ice cap in southern Norway probably disappeared between ca. 8,000 and 6,000 BP [7].

In Denmark, palynological change suggests that the interval between ca. 10,000 and 9,500 BP was the period of the most rapid vegetational change during the Holocene, in both terrestrial as well as lacustrine ecosystems. Corylus was the most abundant between ca. 9,900 and 8,500 BP [8].

In northeastern Poland (Suwalski Landscape Park), Corylus appeared ca. 10,200 cal yr BP. Picea abies (Norway spruce) declined ca. 9,500 cal yr B, as the climate had become too warm for the Picea [9].

In southern Finland, the HTM was between ca. 8,000 and 5,700 cal yr BP. Corylus avellana was then growing approximately $300 \mathrm{~km}$ farther north than it is today, indicating even $2.5^{\circ} \mathrm{C}$ warmer temperatures than today [10].

Southern Europe lacks convincing records that would show that Holocene warming would have exceeded present-day temperatures. The HTM seems to have been non-existent in that region [3].

In Newfoundland, south of the Davis Strait, there is evidence of Holocene warming from ca.10,400 BP onwards [11]. Baffin Bay, north of the Davis Strait, remained densely ice covered until ca. 7,400 cal yr BP, when the warmer waters started to penetrate into the bay [12].

During the second half of the Holocene (between 6,000 and $4,500 \mathrm{BP}$ ) the temperature started to decline. This interval is called the Mid-Holocene cooling. The Jostedalsbreen ice cap reformed permanently at ca. 5,300 BP [7]. Re-expansion of Pinus abies (Norway spruce) occurred in northeastern Poland ca. 4,300 cal yr BP [9]. In southern Finland [13] and in Estonia [14] substantial climate cooling to the present-day level was observed to occur ca. 4,500 cal yr BP. Subsequently the era from ca. $4,500 \mathrm{BP}$ to the present is called the Neoglacial.

Occurrence of millennial scale climate variability can be observed by the advances and retreats of the Høgtuvbreen ice cap between ca. 7,090 and 4,700 BP with the cyclicity of approximately 800 years, and between 4,300 BP and 1900 AD with the cyclicity of 750 years [15].

Reconstructions utilizing many paleo-temperature proxy records would suggest the existence of a distinct Roman Warm Period followed by the Dark Age Cold Period with a cyclicity of 800 years and the Medieval Warm Period vs. the Little Ice Age (LIA) with a cyclicity of 1,100 years (supposed that the LIA ended at $1850 \mathrm{AD}$ ) [16].

The study of foraminifera from sediment cores in Florida suggests that the flow of the Gulf Stream during the LIA was systematically $10 \%$ weaker than it is today. It also suggests that the timing of reduced flow is consistent with temperature minima in several paleoclimate records. This implies that diminished oceanic heat transport (OHT) may have contributed to LIA cooling [17].

Oceanic surface waters are heated in low latitudes. The prevailing NW and SW trade winds create the westbound North and South Equatorial Currents (NEC and SEC, respectively) in the Atlantic and Pacific oceans. In the Indian Ocean only the SEC is formed. These currents are over $1,000 \mathrm{~km}$ wide, which is why they can be divided into northern and southern branches as well.

As they travel across the oceans, the flow of the equatorial currents diverts north in the Northern Hemisphere (NH) and south in the Southern Hemisphere (SH). An important exception is the northern branch of the SEC (nSEC) in the South Atlantic Ocean. In front of the Brazilian tip, it bifurcates into the southbound Brazil Current $(\mathrm{BraC})$ and the northbound North Brazilian Current (NBC) [18]. During the boreal winter, the northward heat transport by the NBC across $10^{\circ} \mathrm{N}$ is on the order of one petawatt (PW) [19]. This is known as northern heat piracy [20].

In the North Atlantic, the NEC flow starts from the coast of northwest Africa (between 10 and $20^{\circ} \mathrm{N}$ ) and moves into the Caribbean Sea where the NBC flow joins it. Then both currents flow into the Gulf of Mexico as the Yucatan Current (YuC). From the Straits of Florida onward, the chain of several currents is called the Gulf Stream Current (GSC). Warm water is conveyed far into the Arctic Ocean.

It is likely that during the GIA the Arctic Ocean was covered by a 900-m-thick floating ice shelf (FIS) below which the water was fresh or brackish [21]. The entire North Sea was covered by grounded ice [22]. The Greenland-Scotland Ridge (GSR) and the Grand Banks of Newfoundland (GBN; then an archipelago) were covered by a thick ice sheet. This all implies that the GSC was not flowing along its present route across the North Atlantic Ocean during the GIA.

As the trade winds are unstoppable, the flow of the NEC is unstoppable. The deficit left by the NEC must be offset, so the flow of the Gulf Stream is also unstoppable. During the GIA, the flow into the Gulf of Mexico might have been prevented by a watertight obstacle, such as a land bridge, in the Yucatan Channel. It would have directed the flow of the Great Ice Age Gulf Stream (GIA-GS) to a more southern route towards the coast of northwest Africa. About 11,700 years ago, an earthquake might have cut the land bridge connecting the gulf to the Atlantic Ocean. This would have allowed the GSC to establish its present flow route via the Straits of Florida [23].

The onset of the Holocene was not synchronous across the North Atlantic Ocean. In northeastern America the overall Holocene climatic amelioration north from the 
Davis Strait lagged considerably compared to that south of the Davis Strait. The temporal appearance of the HTM was not synchronous within Europe.

The observed temporal and spatial dissimilarities require a dominant force with selectively oriented heat transport and a localized mode of action. It seems plausible that the flow of the Gulf Stream could be the main driving force in the onset of Holocene warming and the HTM. Possible long-term cyclicity in the flow rate of the GSC may trigger the observed millennial climate variability.

\section{Materials and Methods}

\subsection{Aims of the Study}

The aim of this meta-study is to provide an understanding of the Atlantic Ocean Circulation as the driving force for the Holocene Thermal Maximum and Millennial Scale Climatic Variability.

\subsection{Methods of Study}

Palynological and palaeobotanical studies cited in the literature are used to clarify the major compositional changes, forest ecosystems have undergone during the Holocene at mid to high latitudes across the North Atlantic Ocean. Betula (birch), Picea (spruce) and Pinus (pine) are recognized as cold tolerant trees, Corylus (hazel) and Quercus (oak) as thermophilous trees.

Palaeo-glaciological studies of the glaciers (especially in Norway) cited in the literature are aimed to study the millennial-scale climatic patterns between cold and warm periods.

The palaeohydrology studies cited in the literature are reviewed against the recent understanding that during the GIA a 900-m-thick floating ice shelf (FIS) was covering the Arctic Ocean and the North Sea was covered by grounded ice. The Greenland-Scotland Ridge (GSR), and the Grand Banks of Newfoundland (GBN) were covered by thick ice sheet. It is further presumed that ca. 11,700 BP the Gulf Stream established the present route through the Straits of Florida into the Arctic Ocean. It is also presumed that below the FIS, the top section of the Arctic Ocean water was to some depth freshwater, while deeper sections might have contained increasingly brackish water.

An important hypothesis to prove is that the temporally and spatially differing changes in the vegetation patterns and retreat and advancement of the mountain glacier were triggered by the flow route changes of the Gulf Stream as it encountered the icy obstacles along its new route.

On the molecular scale, heat diffuses 100 times more rapidly than salt does. In double diffusive convection (DDC) downward moving warm and salty blobs of water exchange heat faster than salt and become denser, which reinforces their initial downward motion. Upward moving cold and fresh blobs of water warm and become lighter, which reinforces their upward motion. As a result, the surface water is freshening and the subsurface water is becoming saltier.

It is aimed to show that due to the melting of ice and due to the DDC in the Arctic Ocean, the inflowing water freshened, and the outflow happened at first through relatively warm surface currents. Due to the gradual increase of the amount of the descending salty water (DSW) formation, the outflow gradually moved as cold undercurrents. For this purpose, a further aim is to clarify the present flows of the surface currents and the undercurrents in the Arctic Ocean.

The 'present' in cal yr BP (calendar years before the present) refers to $1950 \mathrm{AD}$. In many citations, the form $\mathrm{BP}$ (Before Present is used alone). Depending on the publication year, BP dates differ slightly from cal yr BP dates. In this article, BP refers to cal yr BP.

One Sverdrup (Sv) is $10^{6} \mathrm{~m}^{3} / \mathrm{s}$. A pressure of one technical atmosphere (at) equals one kilogram-force per square centimeter.

\subsection{Calculation of the Annual Formation of the DSW in the Arctic Ocean}

The amount of DSW by brine ejection from the ice in the Arctic Ocean is calculated by the following proportion (1):

$$
\frac{a}{b}=\frac{c}{d}
$$

where $a$ is the salt increment which causes the sinking of $b$ $\left(=1 \mathrm{~m}^{3}\right)$ of surface water, $c$ is the total amount of salt ejected $(\mathrm{kg})$ and $d$ is the annually formed amount of DSW in cubic meters.

The increment $a$ is the difference of the salt concentration of the surface water at the moment when DSW starts to descend (34.75\%), and the salt concentration just before the freezing starts $(32.5 \%)$. This results in $a=34.75 \mathrm{~kg}-32.5 \mathrm{~kg}=2.25 \mathrm{~kg}$.

The area of the annually forming ice, first-year ice (FYI) is taken to be $9,100,000 \mathrm{~km}^{2}$ and the thickness of the ice 2 $\mathrm{m}$. The volume of the FYI is $1.82 \times 10^{13} \mathrm{~m}^{3}$.

For calculating $c$, the residual salt concentration in the FYI is assumed to be $6 \%$ [24]. Subsequently during the winter from the FYI is ejected $32.5 \%-6 \%=26.5 \%$ or $26.5 \mathrm{~kg} / \mathrm{m}^{3}$ of salt. The total amount of salt would be 26.5 $\mathrm{kg} / \mathrm{m}^{3} \times 1.82 \times 10^{13} \mathrm{~m}^{3}=4.8 \times 10^{14} \mathrm{~kg}$. Now d $=\mathrm{c} \times \mathrm{b} / \mathrm{a}=$ $2.1 \times 10^{14} \mathrm{~m}^{3}$.

Taken the effective freezing time to be 6 months, the flow created by the DSW is $2.1 \times 10^{14} \mathrm{~m}^{3} / 1.5552 \times 10^{7} \mathrm{~s}=$ $1.35 \times 10^{7} \mathrm{~m}^{3} / \mathrm{s}=13.5 \mathrm{~Sv}$. Outside the proper freezing time the flow is continued mainly by the law of inertia (Newton's first law of motion). Taking the reduction to be $30 \%$, the flow is then $9.45 \mathrm{~Sv}$, giving the total flow volume of $23 \mathrm{~Sv}$ for the DSW.

The mass of the DSW (in one second) is $23 \times 10^{9} \mathrm{~kg}$. Taking the area to be $9.1 \times 10^{6} \mathrm{~km}^{2}$, it would create a downward pressure of $2.3 \times 10^{10} \mathrm{~kg} / 9.1 \times 10^{12} \mathrm{~m}^{2}=2.53 \times$ 
$10^{-3} \mathrm{~kg} / \mathrm{m}^{2}$, which is $2.53 \times 10^{-7}$ technical atmospheres (at) per second. The annual pressure would be $3.1536 \times 10^{7} \mathrm{~s} \times$ $2.53 \times 10^{-7} \mathrm{at} / \mathrm{s}=7.97$ at. This equals ca. $780,000 \mathrm{~N} / \mathrm{m}^{2}$ [25]. This would be the annual thrust for the outflowing undercurrents in the Arctic Ocean.

\section{Discussion}

\subsection{The Onset of the Holocene}

In addition to the temporal difference of the beginning of abrupt warming between South Greenland, North England and Norway, there is also temporal difference between the melting of the ice sheets. In Faroe Island, it took place ca. 11,300 BP [26], in Scotland ca. 11,000 BP [27]. Lake Vardfjelltjønna, downwards from the Mount Høgtuva maritime glaciers $\left(65^{\circ} \mathrm{N}\right.$ Norway), was deglaciated ca. 10,650 BP [15]. This supports the postulation that ca. $11,700 \mathrm{BP}$ the GSC established the present flow route across the North Atlantic Ocean via the Straits of Florida.

At first, after the earthquake about $11,700 \mathrm{BP}$, the passage through the Straits of the Florida was narrower than it is today due to the existence of the Greater Bahama Islands (GBI). The Florida peninsula was also wider. Some of the NEC and NBC flow may have continued via the GIA-GS (see Figure 1). Due to the slow rise of the sea level, much of the GBI became submerged, forming today's Great Bahama Bank (GBB). Large areas, $60 \%$ or 61,400 $\mathrm{km}^{2}$ of the GBB are today shallower than $5 \mathrm{~m} \mathrm{[28].} \mathrm{Also,}$ the Florida peninsula was reduced to its present form. This facilitated the flow of the Antilles Current (AntC) and that of the Gulf Stream to the northeast. The GIA-GS faded away.

\subsection{Temporal and Spatial Occurrence of the HTM}

\subsubsection{Northeastern America}

Evidence of the presence of boreal conifers as early as $12,400 \mathrm{BP}$ in Connecticut is provided by the occurrence of Picea (spruce) needles [29]. This means that during the late glacial period, northeastern America was not completely glaciated.

Holocene climatic amelioration along the eastern seaboard of North America appears to have begun around the time when warming was observed to occur in Greenland. Palynological data show the rapid expansion of thermophilus woodland taxa, such as the increase in Quercus pollen and presence of Pinus strobus (white pine) needles. This warm period lasted until ca. 10,800 BP [29].

Today the GBN is a relatively shallow bank. In some places the depth is less than $10 \mathrm{~m}$. [30]. Between ca. 11,700 and $10,800 \mathrm{BP}$ the GBN was an ice-covered archipelago which likely diverted the flow of the Gulf Stream into three directions. One branch flowed towards Ireland and Scotland as the (early) North Atlantic Current (NAC), the second branch towards northwest African coast as the (early) Azores Current (AzC) and the third branch towards the west. This third branch then flowed south along the coast, warming the coast of southeastern Canadian and New England. It can be called Nova Scotia Current (NScC). Flow volume may have been considerable. Due to this, it is likely that between ca. 11,700 and 10,800 the HTM existed in northeastern America.

Then, between ca. 10,800 and 10,000 BP the oak and white pine declined, and boreal Picea Abies, Larix (larch), Betula papyrifera (paper birch) and Alnus (alder) species increased, implying climatic cooling, possibly as great as $3-4^{\circ} \mathrm{C}$. This vegetational thermophilous-to-boreal reversal was consistent from northern to southern New England (along approximately 5 latitudes) [29].

An important reason for this is that by ca. 10,800 BP the sea level had risen so that the Gulf Stream was able to flow over the GBN. The NScC ceased to flow, so warm water no longer flowed south along the northeastern American coast (see Figure 1). The second important reason is that the Central Quebec ice dome was then rapidly melting, and its cooling effect on the local atmosphere became a dominant factor (see Figure 1). A large ice sheet would typically generate pronounced anticyclonic conditions which would induce a cold climate with strong katabatic winds (fall winds) to the periglacial area [31].

Lake macrofossil records between ca. 10,000 and 9,000 BP show the presence of Pinus strobus needles and the increase of Quercus pollen. This indicates that a second vegetational reversal, now boreal-to-thermophilous, had occurred. In New England temperatures in this period were likely only one degree below the present levels [29]. By 10,000 BP the importance of the Central Quebec ice dome as a local climatic factor had declined.

It seems that in northeastern America the Holocene Thermal Minimum occurred between ca. 10,800 and $10,000 \mathrm{BP}$.

\subsubsection{Ireland}

Plant colonization in Ireland began between ca. 12,900 and $12,700 \mathrm{BP}$ [32]. This means that Ireland during the late glacial was not completely glaciated.

In Aran Islands, Western Ireland coast, Betula pollen prior to $11,700 \mathrm{BP}$ was scarce. It started to increase ca. 11,500 BP (9\% of the pollen samples) and between ca. 11,270 and 10,850 BP Betula values exceeded 24\%. Corylus was present in Aran Islands ca. 11,500, by ca. 10,900 BP its share of the pollen samples reached $10 \%$. Corylus expansion started ca. 10,800 BP (20\%) and peaked ca. 10,700 BP $(60 \%)$. On the other hand, by ca. 10,700 BP the importance of Betula had greatly diminished due to the expansion of Corylus. [5]. Likely the temperature was uncomfortably hot for Betula as well. Then the HTM began in the Aran Islands.

In northeastern Ireland (Sluggan Bog, $50 \mathrm{~m}$ a.s.l), Betula pollen was ca. 12,350 BP extremely abundant, amounting to 
over $80 \%$ of the total pollen. Nowhere else in Ireland has Betula been found even close to such abundance during those times. This woodland started to decline ca. 12,200 BP. Between 12,160 and 11,720 BP the Betula pollen curve fell to $1 \%$ and rose to $10 \%$. Between 11,720 and 11,000 BP, Betula curve was reduced to $2 \%$ or less. Tree cover diminished locally. Rosaceae, rumex and gramineae grassland developed instead [33].

Considering that it was GIA era, and that Scottish ice sheets were in proximity, the reason for the Betula decline and rise prior to $11,700 \mathrm{BP}$ may be a transient climate deterioration due to momentary glacial advance and retreat. On the other hand, the reason for the decline of Betula after $11,700 \mathrm{BP}$ might be the amelioration of the climate as it was too hot for Betula due to the flow of the GSC.

In addition, in SE Ireland grassland developed at and prior 11,000 BP [34], and in the Isle of Man, according to the pollen data, pre-woodland vegetation lasted for most of the first post-glacial millennium [35].

Betula pollen was scarce in the lowlands of Ireland between 10,700 and 9,700 BP [33]. Then the HTM occurred in Ireland. It is likely that the climate in Ireland cooled slightly after this interval.

Between ca. 9,300 and 8,900 cal BP Corylus pollen was in more than $70 \%$ of the Irish samples [36]. This period represented the boreal hazel maximum in Ireland.

After 10,800 BP the flow of the NAC towards Ireland and Scotland increased gradually. The coast of Scotland diverted the flow northeast towards Norway as the (early) Norwegian Atlantic Current (NwAC) and south through the North Channel. This current can be called the North Channel Current (NCC) (see Figure 1). The flow of the NCC increased at first. Ireland and the Isle of Man then received extra heat, which ended when the NAC started to pass Scotland and the NCC declined. Betula returned to the lowlands.

The focal position of Ireland related to the NAC became weaker. Part of this was compensated for by the increase in the flow rate of the NAC as the sea level rose and the GBN became more and more submerged.

Since then, Ireland has been in a stable focal point of the NAC flow. The climate has likely been rather stable as well. Even during the Neoglacial period no dramatic weather events (cold, warm or dry) have been recorded in Ireland [37].

\subsubsection{England}

In northern England the Holocene began abruptly at ca. $11,550 \mathrm{BP}$. The average summer temperatures rose by about $8^{\circ} \mathrm{C}$ within 100 years in the British Isles [2].

In Cranes Moor (southern England, New Forest) Corylus and Pinus sylvestris (pine) along with spaghnum moss were the dominant plants between ca. 10,500 and 9,650 cal yr BP. A notable reduction in Pinus (30 to $10 \%$ ) occurred ca. 9,650 cal yr BP. This was coupled with an increase in Quercus and Betula. Between ca. 9,500 and 8,800 BP the Corylus pollen exceeded all the other trees together by $75 \%$ for a short period, indicating a clear boreal hazel maximum in England [38]. From 8,750 to 8,150 cal yr BP, Pinus and Corylus pollen decreased, while that of Alnus glutinosa (common alder) and Quercus increased. Around 7,500 cal yr BP there was an expansion of Tilia cordata and Fraxinus excelsior (European ash) [39].

The connection between the North Sea and the English Channel was established ca. 10,000 BP due to the rising sea level. Between ca. 10,000 and 8,000 BP brackish water existed in the Deep Water Channel (chlorinity approximately 13). Full marine conditions in the Southern Bight were reached only ca. 7,000 BP. The sharp increase in yearly average air temperatures in central England between ca. 10,000 and 7,000 BP coincided with these periods [6].

It is likely that from ca. 10,000 to $8,000 \mathrm{BP}$ the outflow from the coast of Norway was directed via the North Sea through the English Channel as the North Sea Current (NSC) (see Figure 1). The freshwater from the melting FIS in the Norwegian Sea, the grounded ice-covered Barents Sea, the glaciers in Norway and the Alps (via the river Rhine) maintained the brackish water conditions in the Southern Bight. Outflow from Ancylus Lake (the predecessor of the Litorina Sea) [40] also contributed. Between 8,000 and 7,000 BP NwAC started gradually pass the Norwegian coast. Brackish water outflow from the Litorina Sea (the predecessor of the Baltic Sea) was still likely flowing through the English Channel.

In England, the HTM came between 10,000 and 7,000 BP, as did that of the boreal hazel maximum. After ca. 7,000 BP, the NwAC already passed totally the Norwegian coast, and likely then also the outflow from the Litorina Sea diverted north as the Norwegian Coastal Current (NwCC). The NSC flow through the English Channel declined. 


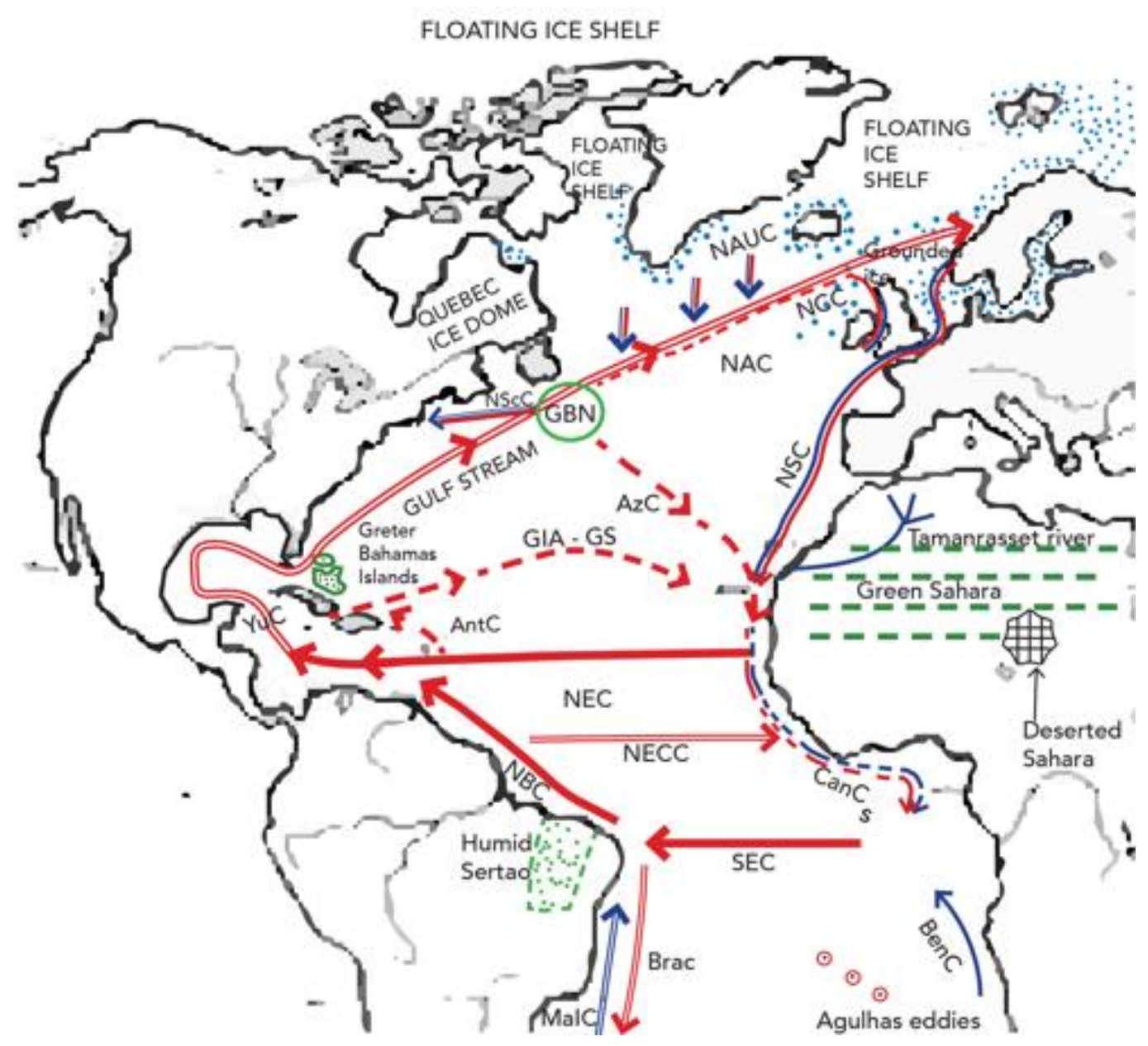

Figure 1. Map of the Gulf Stream flow during the early Holocene.

\subsubsection{Scotland and Faroe Islands}

In Sandoy, Faroe Islands the vegetation dynamics can be followed from ca. $11,250 \mathrm{cal}$ yr BP onwards from a lacustrine sequence. Vegetation replacement occurred ca.10,250 cal yr BP. Then Empetrum arctic heathland shifted to grassland and moist sedge communities. These taxa dominate the modern landscape as well [26].

It is likely that by ca. 11,000 BP the Western Isles, Scotland were deglaciated. From ca. 10,900 BP onwards pollen samples can be detected in the sediments of the Loch Lang. Between about 10,700 and 10,200 BP the area was partially covered by open vegetation of Empetrum $(10 \%-45 \%)$ with grasses, sedges and Huperzia selago (northern firmoss). Pollen frequency for Betula was about $5 \%$. [27].

The last glacier resurgence in Scotland-the Loch Lomond Advance (LLA) - culminated in an ice cap of approximately 9,500 $\mathrm{km}^{2}$ centered over Rannoch Moore [41].

Corylus was one of the first woody species after Betula to establish itself along the western edge of Scotland after 10,000 BP. According to pollen evidences pure hazel scrub dominated vast areas of western Scotland for perhaps a thousand years between ca. 9,500 and 8,500 BP [42]. During this period, there may be also have been the HTM in Scotland.

Since then, Skoctland has been in a stable focal point of the NAC flow like Ireland. The climate has likely been rather stable. Even during the Neoglacial period, no dramatic weather events (cold, warm or dry) have been recorded in Scotland [37].

\subsubsection{Norway}

The complete deglaciation of the Sør-Tverrfjorddalen valley, adjacent to the Langfjordjøkelen ice cap in Arctic Norway $\left(70^{\circ} 10^{\prime} \mathrm{N}, 21^{\circ} 45^{\prime} \mathrm{E}\right)$ occurred ca. $10,000 \mathrm{cal} \mathrm{yr} \mathrm{BP}$. During the peak of the HTM, the glacier was reduced or absent [43].

Glaciers in Nordvestlandet and Jostedalsbreen, Southern Norway disappeared from at least three of the catchments shortly after ca. 9,000 BP. Based on botanical evidence, the whole Jostedalsbreen ice cap probably disappeared ca. 8,000 to 6,000 BP [7]. In general, glaciers in Norway were small and maritime glaciers even absent during the peak of the HTM ca. 9,000 to $6,000 \mathrm{BP}$.

It is likely that the Mount Høgtuva glaciers existed in the 
highest reaches of the catchment between ca. 7,830 and 7,120 cal yr BP. Austre Okstindbreen glacier (near Høgtuva) is the first known glacier in Scandinavia to possibly have survived the HTM [44]. An influx of glacially derived clastic sediments into Lake Vardfjelltjønna ceased by ca. 7,100 BP generally at a very low level [15]. The Jostedalsbreen ice cap reformed permanently ca. 5,300 BP [7]. The end of the HTM in Norway may have taken place around 5,500 BP.

\subsubsection{Finland}

In southern Finland the first peat began accumulating ca. 10,700 cal yr BP [40]. According to pollen stratigraphy studies, the annual mean temperatures between ca. 10,700 and 10,000 cal yr BP were below $0.0^{\circ} \mathrm{C}$, and steadily rising. The period between 8,000 and 6,000 cal yr BP is characterized by maximum values of nemoral deciduous tree taxa, with Corylus, Ulmus, and Tilia reaching their highest percentages. Picea starts to increase at ca. 6,000 cal yr BP. According to reconstructions, the annual mean temperatures were ca. $6.0^{\circ} \mathrm{C}$ [13].

Peatland initiation through paludification (the accumulation of peat directly atop flat to gently sloping mineral soils) ceased almost completely between ca. 7,000 and 6,000 cal yr BP [45]. This probably reflects an increase in temperature up to the point that evapotranspiration was more or less equal to precipitation. This period was likely the peak of the HTM in Finland.

After ca. 5,700 BP, the warm HTM conditions prevailed, with a slightly declining trend. Since the late Holocene $4,500 \mathrm{cal} \mathrm{yr}$ BP to the present, the main features of the pollen stratigraphy are the gradual decline in Alnus, Corylus, Ulmus, and Tilia, and the rise of Pinus and Picea. The declining values of the nemoral taxa are accompanied by a steady fall in temperatures, suggesting an average fall in the annual mean temperature of $1.5^{\circ} \mathrm{C}$ [13].

Leeward of the Scandes mountains much of northern Sweden and Finland was, until ca. 10,500 cal yr BP, covered by an ice sheet. The ice margin then rapidly retreated and the ice sheet had probably completely melted by ca. 10,000 to 9,500 cal yr BP) [46].

Pollen assemblages preserved in a sediment core from Lake Tsuolbmajavri in northern Finland $\left(68^{\circ} 41^{\prime} \mathrm{N}\right.$, $22^{\circ} 05^{\prime} \mathrm{E}$; $526 \mathrm{~m}$ a.s.l.) indicate a gradual warming after deglaciation ca. 9,500 to $8,500 \mathrm{cal} \mathrm{yr}$ BP [47]. Similar results have been obtained from sediment samples from the proglacial lake Vuolep Allakasjaure in northern Sweden, about $250 \mathrm{~km}$ southwest of Tsuolbmajavri [48].

The pine mega fossil evidence suggests a clear warming stage during which the pine tree-line was located approximately $200 \mathrm{~m}$ higher than it is at present. The expansion of the pine to high altitudes was amplified from ca. 7,000 cal yr BP onwards [49]. The maximal occurrence of pine mega fossils from above and beyond the present pine tree-line in Finland dates to ca. 5,950 to 4,150 cal yr BP [50].

\subsubsection{Poland}

Poland was not covered by glaciers ca. 11,700 BP. There the onset of the Holocene ca. 11,600 cal yr BP is marked by the decline of shrub vegetation [45]. In southeastern Poland (Bieszczady Mountains) the contribution of Picea abies (Norway spruce) increased up to approximately $10 \%$ of the pollen spectra in the period 11,500 to $10,700 \mathrm{cal}$ yr BP. From there, spruce spread also to northeastern Poland (Suwalski Landscape Park). Corylus avellana appeared in the area ca. 10,200 cal yr BP [9].

Around 10,000 cal yr BP the Norway spruce started to decline, as the climate was likely to become too warm for the Picea. In addition, by ca. 9,500 cal yr BP Ulmus, Tilia, and Quercus had dynamically expanded in the area. Spruce could not compete with these thermophilic trees and subsequently disappeared. A massive re-expansion of Picea in the Suwalski Landscape Park area, Poland occurred ca. 4,300 cal yr BP [9].

\subsubsection{Labrador Sea and Nares Strait}

Newfoundland was covered by an ice sheet until ca. 10,000 BP [51]. It is likely that there was also a FIS (possibly less than $900 \mathrm{~m}$ thick) in the eastern Labrador Sea and Baffin Bay (see Figure 1). The West Greenland Current (WGC) penetrated into Baffin Bay ca. 7,400 BP [12]. The freshwater below the FIS was salinated with the simultaneous decrease in WGC speed. A stronger WGC inflow to the Labrador Sea and Baffin Bay started ca. 7,000 BP [52].

The decrease in WGC speed demonstrates that the salination was due to the double diffusive convection (DDC): Warm salty water cools and starts to descend when it flows atop cold freshwater, then the cold freshwater warms and starts to ascend [53-54]. The horizontal movement of warm water then slows down.

Petermann Fjord, Nares Strait did not deglaciate until ca. 7,600 cal yr BP [55]. Between ca. 6,900 and 5,500 cal yr BP sea-ice biomarker and foraminiferal fluxes in Petermann Fjord and Kane Basin (part of the Nares Strait) indicate reduced seasonal sea-ice occurrence alongside summer coastal melt and seasonally open water around NE Greenland and Ellesmere Island [56].

Temporally, the onset of the Holocene north of the Davis Strait was lacking from that which occurred south of the Davis Strait. It seems that there was no special HTM north of the Davis Strait.

\subsection{Observations Suggesting Millennial Cyclicity during the Late Holocene}

Fossil tundra fragments consisting chiefly of Arctic mosses Rhacomitrium lanuginosum (woolly fringe-moss; $60 \%$ ) and Dicranum (fork mosses; 20\%) were found in the forefield of Werenskioldbreen glacier, Spitsbergen. The vegetation formed a cover about $5 \mathrm{~cm}$ thick and occurred between two till layers. The samples taken for radiocarbon 
analysis in 1973 came from a position $25 \mathrm{~m}$ a.s.l., located about $450 \mathrm{~m}$ from the glacier front. In 1957 the area was still completely covered by ice. The age of the upper part of this layer was dated to $760 \pm 145$ years BP and the lower part to $1,565 \pm 235 \mathrm{BP}$ [57]. This suggests a cycle of 805 years from warm period via cold period back to warm period.

In the period between ca. 7,120 and 4,400 cal yr BP, the influx of glacially derived clastic sediments in Lake Vardfjelltjønna was generally very low. The only exceptions are three warmer periods of slightly increased influx of $\mathrm{K}$ centered between ca. 7,090 and 6,610, 6,170 and 5,700, and 5,340 and 4,700 cal yr BP, respectively. During these periods, the equilibrium line altitude (ELA) of the Mount Högtuva glaciers has fluctuated between 961 $\mathrm{m}$ (cold period) and $1020 \mathrm{~m}$ (warm period) [15]. The cyclicity of the periods was about 800 years.

A distinct glacier advance, with an ELA depression down to $920 \mathrm{~m}$, has been reconstructed for the period between ca. 4,420 and 4,300 cal yr BP. This is suggested to indicate the onset of the Neoglacial subperiod of the Holocene at Høgtuva. In the nearby Austre Okstindbreen ice cap, a synchronous glacier advance was observed to have taken place at around the same time [44].

After a short-term rise in the reconstructed ELA to 980 $\mathrm{m}$ at mount Høgtuva, the ELA dropped to $780 \mathrm{~m}$ between ca. 3,920 and 2,660 cal yr BP. Fluctuation periods were then between ca. 3,830 and 3,540, and ca. 3,270 and 3,065 cal yr BP, suggesting a cyclicity of 765 years. Mass balance measurements from 1971 to 1977 AD indicate that at present Norwegian glaciers have a mean ELA of $847 \mathrm{~m}$ [58].

According to reconstructions, there have been eight distinct glacier advances and retreats in Høgtuva between ca. 4,400 BP and $1900 \mathrm{AD}$ [15]. This would suggest a cyclicity of 790 years from glacier retreat to (warm period) via glacier advance (cold period) to the start of a new cycle.

Scientific evidences from the North Atlantic deep-sea cores reveal changes between warm and cold climates during the entire Holocene. During each of these episodes, cool, ice-bearing waters from north of Iceland were advected as far south as the latitude of Britain. At about the same time, the atmospheric circulation above Greenland changed strongly. The duration of the cyclicity was estimated to be $1,470 \pm 500$ years. Cycles are suggested to be linked to the circulation of the North Atlantic Ocean's currents [59].

According to palaeoclimatic evidence (pine pollen data from Chesapeake Bay), a series of Holocene millennial-scale cool intervals in eastern North America has taken place during the Holocene, occurring about every 1,400 years and lasting approximately 300 to 500 years [60].

Considering the possibility of turbulence due to the flowing water above and of bioturbation, these estimates of 1,400 to 1470 years should be regarded as more unreliable than the other measurements mentioned above.

Table 1. Summarizing the results for comparison across regions

\begin{tabular}{|c|c|c|c|c|}
\hline Region & $\begin{array}{c}\text { Start of the Holocene } \\
(\mathbf{B P})\end{array}$ & $\begin{array}{c}\text { Holocene Thermal } \\
\text { Maximum, HTM (BP) }\end{array}$ & $\begin{array}{c}\text { Boreal hazel maximum } \\
(\mathbf{B P})\end{array}$ & $\begin{array}{c}\text { Holocene Thermal } \\
\text { Minimum (BP) }\end{array}$ \\
\hline New England & 11,700 & $11,700-10,800$ & - & $10,800-10,000$ \\
\hline Ireland & 11,700 & $10,700-9,700$ & $9,300-8,900$ & - \\
\hline England & 11,550 & $10,000-7,000$ & $9,500-8,800$ & - \\
\hline Faroe Islands & $11,300^{*}$ & Not observed & Not observed & - \\
\hline Scotland & $11,000^{*}$ & $9,500-8,500$ & $9,500-8,500$ & - \\
\hline Norway & $10,650^{* *}$ & $9,000-5,500$ & $8,000-5,500$ & - \\
\hline Southern Finland & $10,600^{*}$ & $8,000-5,700$ & $8,000-5,700$ & - \\
\hline Newfoundland & $10,000^{*}$ & Not observed & - & - \\
\hline Northern Finland & $10,000-9,500^{*}$ & $8,000-5,700$ & - & - \\
\hline Baffin Bay & $7,400^{* * *}$ & Not observed & - & - \\
\hline Nares Strait & $6,900^{* * *}$ & Not observed & - & - \\
\hline Arctic Ocean & $6,000^{* * * *}$ & Not observed & - & - \\
\hline
\end{tabular}

*melting of the ice sheet, **melting of the maritime glaciers, ${ }^{* * *}$ melting of sea ice in summer, ****melting of the FIS 
Historical evidence suggests that Europe experienced relative warmth during the medieval interval from roughly 900 to 1300 [60]. That was followed by the LIA, which is dated from 1300 to $1850 \mathrm{AD}$ [62].

The winter of 1708-09 in Europe was so cold that it was known as the Great Frost [63]. It is the coldest European winter of the past 500 years [64]. In February 1658, the ice in the Great Belt sound was so thick that the king of Sweden, Charles X Gustav, could lead his army on attack from the island of Fyn to Sjælland island [65].

Atmospheric temperature responds more quickly to changes in the OHT by the GSC than do glaciers, which are at sub-zero temperatures. There should be a lapse in time during which the mountain glaciers react to slowly increasing OHT. Temperate glaciers such as those in the Alps started to retreat ca. $1850 \mathrm{AD}$ and cold glaciers, such as those in the Ural, started to retreat at the beginning of the 20th century. Presuming that the flow of the GSC started to increase ca. $1700 \mathrm{AD}$, the lapse in time is 150 and 200 years.

It can be approximated that the LIA ended between 1650 and $1700 \mathrm{AD}$. Presuming that the duration of the full cycle of increasing flow (warm) to decreasing flow (cold) is 750 to 800 years, the end of the Medieval Warm Period would have been ca. 1250 to $1300 \mathrm{AD}$ and its onset 850 to $900 \mathrm{AD}$. This would suggest that the next turnover from increasing flow to decreasing flow would take place between 2050 and $2100 \mathrm{AD}$.

\subsection{The Arctic Ocean Inflow and Outflow}

\subsubsection{Inflow of Surface Currents (GSC)}

As a chain of surfaces currents, the flow of the GSC into the Arctic Ocean is not steered by bottom topography. The thrusts created by the flow of the NEC and the westerlies are stable driving forces for the GSC. The flow of the GSC likely has a positive feedback on the westerlies as well. An important driving force of the GSC is also the suction created by the DSW in the Arctic Ocean.

The first section in the chain of the Gulf Stream Currents (GSC) is the Florida Current (FloC). At around the Cape Hatteras the next section in the chain is the Gulf Stream, which flows northeast over the GBN. The single flow bed of the Gulf Stream is characterized by wavy perturbations, known as Gulf Stream meanders and eddies. After the GBN, the flow volume of the NAC is 35 to $38 \mathrm{~Sv}$ in multiple, branching fronts.

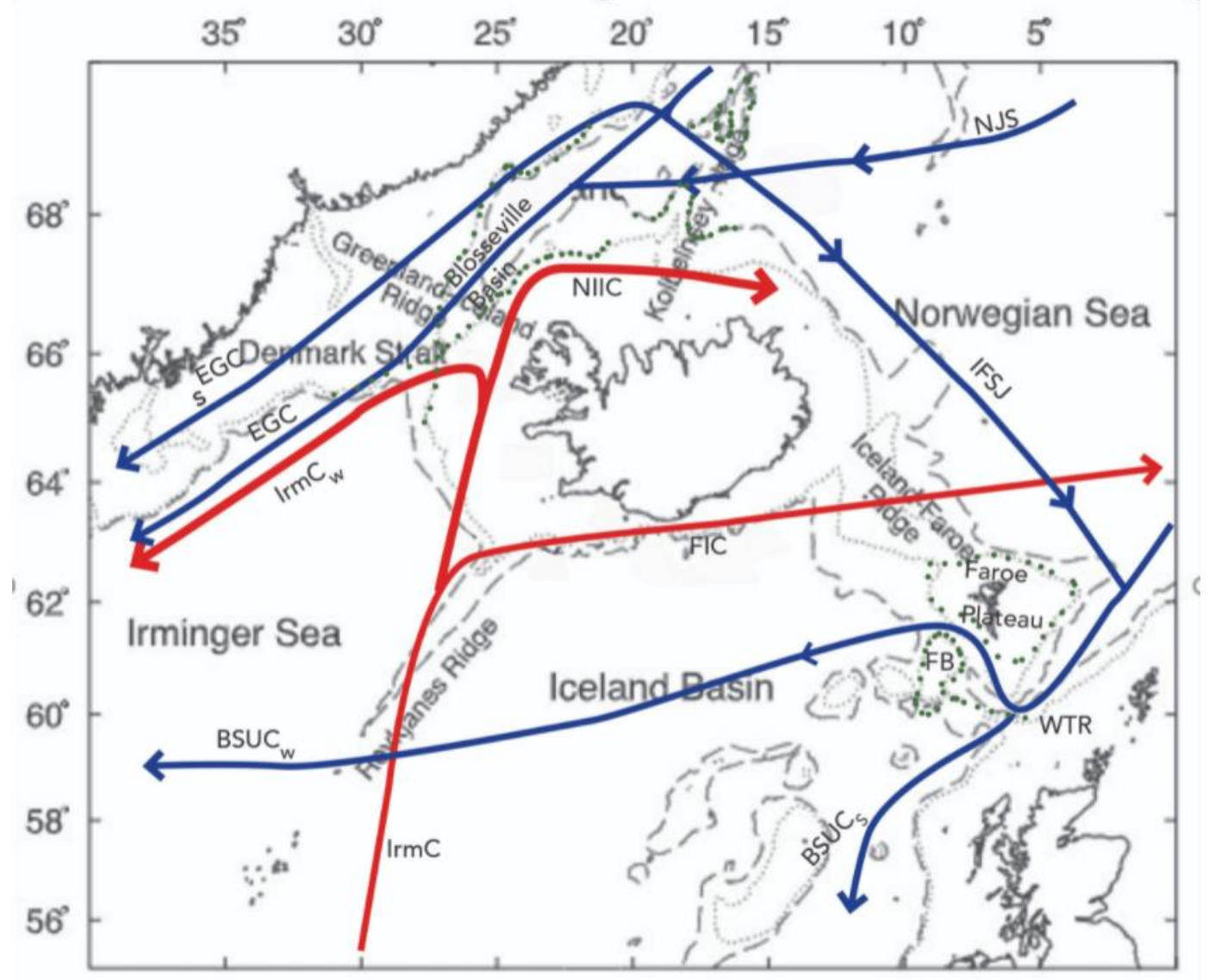

Figure 2. The Greenland—Island and Island—Faroe ridges and Islandic Sea currents. Depth contours are 500 and $1000 \mathrm{~m}$. Drawn on the map from [67] 
At around $54^{\circ} \mathrm{N}, 32$ to $28^{\circ} \mathrm{W}$ the Irminger Current (IrmC) branches north [66]. Then its volume transport is estimated to be $12 \pm 3 \mathrm{~Sv}$ [67]. As it approaches the southwest Icelandic waters, the Faroe Island Current (FIC) branches east north of the Faroe Islands. According to long-distance drifter experiments, the FIC flow joins to NwAC. Some drifters had drifted as far north as the west of Spitzbergen and some into the Barents Sea [68].

In the midwestern Icelandic waters from the IrmC is branching the westbound Irminger Current $\left(\mathrm{IrmC}_{\mathrm{W}}\right)$ and in northwest Islandic waters the IrmC is veering to flow east along the north coast of Iceland. Then it is called the North Iceland Irminger Current (NIIC) (see Figure 2).

On the Norwegian coast (at the level of the Svinøy lighthouse $\left(62^{\circ} 20^{\prime} \mathrm{N}, 5^{\circ} 16^{\prime} \mathrm{E}\right) \mathrm{NwAC}$ flow is divided into eastern and western branches. Both have a width of 30 to $50 \mathrm{~km}$, while the annual mean flow of eastern branch is 4.2 $\mathrm{Sv}$ and that the western branch is 3.4 Sv [69]. FIC flow enters the NwAC farther north, which increases the flow volume. The NwAC branches at about $67^{\circ} \mathrm{N}, 3^{\circ} \mathrm{E}$ to the northbound West Spitsbergen Current (WSC) and eastbound North Cape Current (NCaC) (see Figure 3) [70]. At the moment the flow of the $\mathrm{NCaC}$ is increasing [71]. Similarly, the 10-year running mean of (annually interpolated) mean temperatures between 20 and $200 \mathrm{~m}$ in the core of the WSC increased from $4.4^{\circ} \mathrm{C}$ in 1963 to $5.8^{\circ} \mathrm{C}$ in 2016. This represents an increase of $1.4^{\circ} \mathrm{C}$ in 52 years, or $0.27^{\circ} \mathrm{C}$ per decade [72].

From the WSC branches the Return Atlantic Current (RAC) west and south in the Fram Strait between $78^{\circ} 30^{\prime} \mathrm{N}$ and $79^{\circ} \mathrm{N}$. At the northern part of the Fram Strait (approximately $80^{\circ} \mathrm{N}$ ), the WSC splits further into the Svalbard Branch (SB) and the Yermak Branch (YB) [73]. RAC is likely diverting the flow of the $\operatorname{IrmC}_{\mathrm{W}}$ to the southwest in the Denmark Strait.

Farther east in the Barents Sea, the $\mathrm{NCaC}$ branches to the North Novaya Zemlya Current (NNZC), which passes Cape Zhelaniya of Severny Island into the Kara Sea. There it flows with a velocity of 5 to $10 \mathrm{~cm} / \mathrm{s} \mathrm{SW}$ along the eastern coasts of the Novaya Zemlya islands. The flow of the South Novaya Zemlya Current (SNZC) is directed to the Kara Sea via the Yugorsky Strait with a velocity of 60 $\mathrm{cm} / \mathrm{s}$ and through the strait between Yuzhny and Vaygach Islands with a velocity of $20 \mathrm{~cm} / \mathrm{s}$ [74].

The Norwegian Coastal Current (NwCC) originates in Skagerrak as a continuation of the Baltic Sea outflow, wedged by the NwAC and pushed by the northeast winds it flows along the Norwegian coast all the way up into the Barents Sea. [75]. The total flow volume of the NwCC is $1.8 \mathrm{~Sv}$. [76]. It is likely that the NwCC rather than the $\mathrm{NCaC}$ keeps the coasts of the Norwegian and the Kola peninsula free of ice throughout the year (see Figure 3).

The existence of polynyas and leads in the Arctic Ocean and the thinning of the multi-year ice (MYI) are evidencing that the flow of the warm GSC surface water extends practically everywhere in the Arctic Ocean.

\subsubsection{Formation of the DSW}

The freezing of surface water (at a temperature of $1.9^{\circ} \mathrm{C}$ ) over the Antarctic continental shelf produces brine with a salinity of $34.62 \%$. The density of the sea water is $1,027.89 \mathrm{~kg} / \mathrm{m}^{3}$, which causes brine to sink [77-78]. The same physics applies in the Arctic Ocean as well. Here this kind of water is called descending salty water (DSW). Under the ice, there is no wind, so the density gradient perseveres. Sinking of the DSW removes surface water, creating the cold undercurrents and the suction of the GSC. There is an immediate on/off contact between the incoming and outgoing water.

The ice in the Barents Sea and Greenland Sea, Baffin Bay and the Labrador Sea as well in the shallow seas of the Arctic Ocean freezes and melts annually. They are perennially ice free or first year ice (FYI) sea areas. The ice thickness increases up to $2 \mathrm{~m}$. In the Central Arctic Ocean (the Canada, Makarov and Nansen basins), the ice cover consists of multi-year ice (MYI). The overall thickness of the MYI in summer is 1.5 to $3 \mathrm{~m}$. During the winter, the thickness increases by 0.5 to $1 \mathrm{~m}$ to 2.5 to $3.5 \mathrm{~m}$. Ice is a good insulator, so thinner ice grows faster than thicker ice. The FYI covered areas produce DSW per square kilometer over $50 \%$ more than the MYI covered areas.

At present, the Arctic Ocean is rapidly losing MYI, covering now less than a third of the Arctic Ocean [79]. In addition, the thickness of the remaining MYI is decreasing [80]. On the other hand, the amount of winter ice in the Arctic Ocean is increasing [81]. This indicates that the DSW formation is presently increasing.

The inflow of the GSC water into the Arctic Ocean is via the IrmC $12.5 \mathrm{~Sv}$, via the NwAC 7.6 Sv and via the NwCC $1.8 \mathrm{~Sv}$ (see Section 3.4.1). These inflows together total $21.9 \mathrm{~Sv}$. The estimated annual volume of the DSW varies between $15 \pm 2 \mathrm{~Sv}$ [82] and $23 \mathrm{~Sv}$ (see Section 2.3). The average annual pressure created by the DSW would be $780,000 \mathrm{~N} / \mathrm{m}^{2}$. This thrust is the driving force for the undercurrents in the Arctic Ocean. The amount of the annually freezing water eventually determines the strength of the suction of the GSC.

During the summer months only a small amount of water freezes in the Arctic Ocean. At that time the formation of the DSW is at the minimum. Then it is mostly formed by salt residues in the melting ice. Suction decreases dramatically. However, due to inertia (according to Newton's first law) outflow continues, though with smaller volume. This causes an annual fluctuation in the outflow from the Arctic Ocean, which can be detected as minimum flow periods in the Labrador Current (LabC) [83] and Canary Current (CanC) [84] as well. This shows that both of these currents carry the DSW from the Arctic Ocean. The suction created by the DSW is a changing driving force for the GSC.

\subsubsection{Outflowing Undercurrents}

The driving force for the undercurrents in the Arctic 
Ocean is the thrust created by the DSW. The outflow is steered by bottom topography. That is why the outflow is restricted to a few key points.

The DSW formed in the FYI areas of the Laptev Sea, East Siberian Sea and Chukchi Sea (on the East Siberian Shelf) are conveyed to the Canada, Makarov and Nansen basins towards the Fram Strait which is the only deep route for DSW out from the Central Arctic Ocean into the Greenland Sea. This undercurrent can be called the East Siberian Shelf Undercurrent (ESSUC). Its surface part is known as the Transpolar Drift [85]. The East Greenland Current (EGC) is the continuation of the ESSUC (see Figure 3).

For the DSW formed in the FYI areas of the Laptev and Barents Seas, the only way into the Norwegian Sea is the Bear Island Channel between Svalbard and Norway (in the
Barents Sea Opening). This undercurrent can be called the Barents Sea Undercurrent (BSUC).

Due to the bottom topography of the Arctic Ocean the outflow is restricted to a few key points. In the southern Norwegian Sea the Iceland-Faroe-Scotland Ridge (IFSR) separates the deep parts of the Norwegian Sea from the Iceland Basin and West European Basin in the proper North Atlantic Ocean (see Figures 2 and 3).

In the IFSR the L-shape Faroe-Shetland Channel (FSC) is the only deep route through the IFSR. The Wyville Thomson Ridge (WTR) at the depth of 500m separates the southern aisle of the FSC "L" from the West European Basin. It diverts most of the BSUC water to the flow into the 800-m-deep western aisle of the FBC "L" between the Faroe Bank (FB) and Faroe Plateau. This current can be called $\mathrm{BSUC}_{\mathrm{W}}$ (see Figure 2).

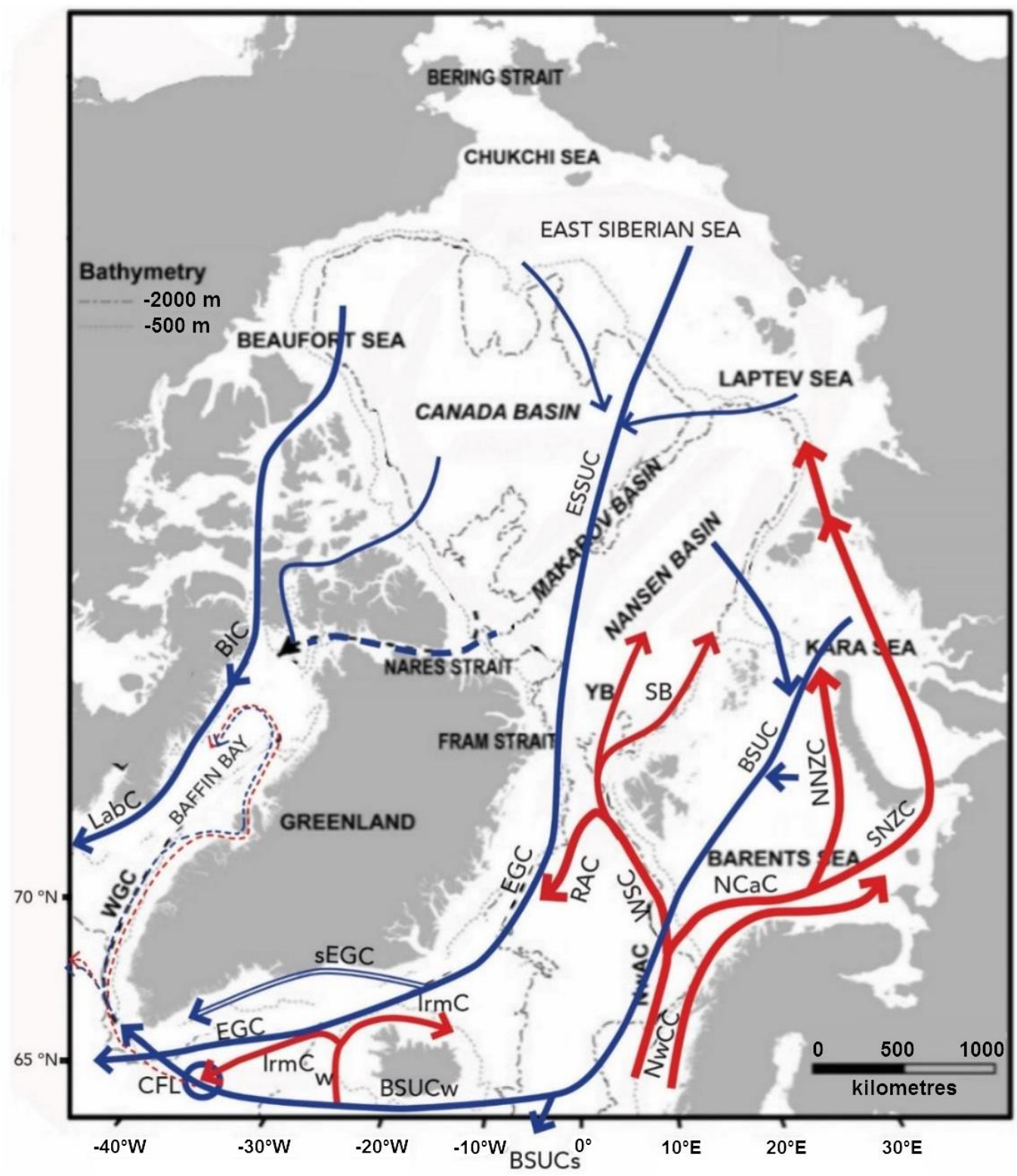

Figure 3. Arctic Ocean surface (red) and undercurrents (blue) currents. CFL = confluence. Drawn on the map from [89] 
BSUC $_{W}$ flows through the Reykjanes Ridge (RR) via the Bight Fracture Zone into the Irminger Sea in the Island Basin and further into the Labrador Sea. Southeast from Cape Farwell, the $\mathrm{BSUC}_{\mathrm{W}}$ confluences with the $\mathrm{IrmC}_{\mathrm{W}}$. This creates the West Greenland Current (WGC; see Figure 3).

A buoy drifting at a depth of $75 \mathrm{~m}$ was released in Denmark Strait into the shelfbreak of the East Greenland Current (sEGC). It ultimately floated into the WGC [86]. This implies that there might be a second confluence with the $\mathrm{SEGC}$ as well.

However, the density of stagnant water of the Atlantic Ocean in the southern side of the WTR can hardly be a watertight obstacle for less dense flowing water brought by the BSUC. Some percolation of the BSUC water takes place south [87-88]. This flow can be called the BSUC $_{\text {s }}$. Just after the WTR starts the Rockall Trough, which leads the BSUC $_{S}$ water into the Porcupine Abyssal Plain in the West European Basin. Ultimately this cold water upwells in the west coast of Iberia and northwest coast of Morocco.

DSW formation in the FYI areas of Beaufort Sea and Canadian Basin are the starting points of the Baffin Island Current (BIC). DSW from the FYI areas of Labrador Sea and Hudson Bay increases the flow of the LabC.

The research of the Arctic Ocean undercurrents is still developing. The North Icelandic Jet (NIJ) was found in 2001. It is a deep-reaching $(600 \mathrm{~m})$ and narrow (15 to 20 $\mathrm{km})$ barotropic jet with measured speeds exceeding 40 $\mathrm{cm} / \mathrm{s}$. Its flow volume is more than $1 \mathrm{~Sv}$. It flows on the continental slope of Iceland [90]. NIJ is likely a branch of the BSUC. Its flow causes the bifurcation of the EGC to sEGC in the Blosseville Basin (see Figure 2) [91].

The Iceland-Faroe Slope Jet (IFSJ) was found in 2020. It is a deep current following the northern slope of the GSR from Iceland toward the Faroe Islands [92]. It likely is a branch of the ESSUC.

In the proper North Atlantic Ocean, an important additional driving force for the cold undercurrents is the suction created by the flow of the NEC in the Northwest African coast. From the Labrador Sea, the DSW flows as the North Atlantic Undercurrent (NAUC) to the starting point of the NEC. Due to Bernoulli's law, the flow is widening [91]. The measurement of the integrated volume transport of sea currents at depths of 200 to $800 \mathrm{~m}$ around the coast of Northwest Africa can be linked to the arriving NAUC flow as a wide front [93]. The upwelling NAUC water flows into the CanC and farther into the NEC.

The unequal water balance created by the NBC flow must be balanced. According to kinetic studies, there is an undercurrent flowing towards the shoreline in the Gulf of Guinea. The maximum kinetic energies are measured at surface down to $200 \mathrm{~m}$ and at a depth of approximately 800 $\mathrm{m}$ [94]. It is likely that this is NAUC water flowing over the equator as a southern continuation of the CanC, called here the $\mathrm{CanC}_{\mathrm{S}}$ flowing into the starting point of $\mathrm{nSEC}$. The water budgets between North and South Atlantic Oceans are balanced, but the heat budgets between these two oceans become even more unbalanced.

\subsection{Flow of the Gulf Stream during the Holocene}

The abrupt rise of atmospheric temperature ca. 11,700 BP had a dramatic effect on the annual formation of the sea ice as well. The winter ice line retreated in a very short time (maybe in the span of a few decades) to follow the border of the FIS line in the Labrador Sea and the ice-covered GSR.

The formation of the DSW was very low. Outflow took place as surface currents having $\mathrm{T} \approx 0{ }^{\circ} \mathrm{C}$. Today, the outflow has $\mathrm{T} \approx-2{ }^{\circ} \mathrm{C}$. Due to this, the NEC and nSEC received rather warm compensation water. The NBC and the GSC waters were also warmer than they are today. This is a likely explanation of why the overall temperature during the Holocene before the Neoglacial was approximately $2{ }^{\circ} \mathrm{C}$ warmer.

At first, the GBN was a serious obstacle for the Gulf Stream. Due to the NScC and AzC flow, the NAC was reduced to maybe even a third of the total flow. The veering of the NCC from the NAC by the coasts of Ireland and Scotland further reduced the flow of the NwAC towards the Norwegian coast. This all slowed the melting of the grounded ice in the northern North Sea. It took more than 1000 years until the sea level had risen so that the Gulf Stream could freely flow over the GBN. Then the flow of the NAC increased, it started to pass the coasts of Ireland and Scotland. The NwAC flow also increased, and ca. 10,000 BP this flow reached the coast of Norway (see Figure 1).

After that, flow of the NwAC was restricted by the FIS in the Norwegian Sea in the north and the grounded ice-covered Barents Sea in the east. Due to that the NwAC diverted by the coast of Norway for approximately 2,000 years to flow south through the English Channel as the NSC. Freshwater from the melting ice kept outflow and the Southern Bight water brackish.

Sediment core samples from the Reykjanes Ridge, in the location over which IrmC flows today, provide evidence of relatively low and highly variable sea surface temperatures (SST) during the early Holocene interval from ca. 11,000 to 7,500 BP. The surface conditions were highly variable, with episodes of temperature fluctuations of 2 to $4^{\circ} \mathrm{C}$ amplitudes and high amplitude fluctuations in the diatom assemblages [95]. In the mountainous areas the ELA fluctuation can be observed as well. However, these fluctuations were much smaller than during the Neoglacial period.

As there was still no immediate on/off connection between the incoming and outgoing water, the incoming water tended to accumulate. SSTs were then higher. When the uphill was high enough, the incoming flow started to slow and the outflow increased. SSTs were then lower. Then the inflow started to increase again. This is a likely mechanism for the retreat and advances of the glaciers observed during the Early and Mid-Holocene. 
The overall decrease and increase of the temperature on a millennial scale during the Early and Mid-Holocene fluctuation episodes, however, were so small that it is difficult to determine by the pollen and macro fossil samples in the lowlands of Europe. Outflow (compensation water) for NEC, nSEC was all the time warmer than they are today. This suggests the NBC and the GSC flows were warmer as well.

A strong IrmC flow occurred from ca. 7,500 to 5,000 BP, resulting an interval of increasing SSTs [95]. Strong WGC flow into the Baffin Bay started ca. 7,000. This implies that the $\mathrm{BSUC}_{\mathrm{W}}, \mathrm{sEGC}, \mathrm{EGC}$ and NAUC flows were all operational, to some extent at least.

For the flow of the IrmC the final interval from ca. 5,000 $\mathrm{BP}$ to present reveals cooler and relatively more stable conditions compared to the period between ca. 11,000 and 7,500 BP [95]. Around ca. 6,000 BP the Sahara started to dry in earnest indicating that the flow of the NAUC was increasing.

Peat- and pollen-stratigraphical records from Petsamo, northwest Russia, show a distinct activation of paludification processes between ca. 5,100 to 4,400 BP and subsequent spread of peatlands [96]. Peat accumulation requires that annual precipitation exceeds evapotranspiration. As after ca. 5,000 cal yr BP no water is added to the world's oceans [97] it is obvious that ca. 5,100 to $4,400 \mathrm{BP}$ the flow of NwCC was increased to the level which keep the Barents Sea coastline open in front of Petsamo throughout the year.

Likely before ca. 6,000 BP was the last of the FIS in the central Arctic Ocean and that of the grounded ice in the shallow seas in East Siberian Shelf melted. Ice did not obstruct the flow of the surface currents in the Arctic Ocean. Flows of ESSUC and BSUC started to gain more strength.

Between 6,000 and 4,500 BP was the Mid-Holocene cooling. During that interval, salination of the brackish water in the Central Arctic Ocean occurred through the DDC mechanism. This fresher water absorbed the salt from the water brought by the WGC and $\mathrm{NCaC}$. The salination of the water took place through DDC. It was a slow process, lasting approximately 1,500 years until the Arctic Ocean surface water obtained its full marine salt concentration. DSW formation and the suction of the GSC became fully operationally.

The Neoglacial began ca. 4,500 BP. Since then, between the inflow and outflow water has been an immediate on/off contact, and mainly cold (approximately $-2^{\circ} \mathrm{C}$ ) undercurrents have been removing GSC water from the Arctic Ocean. NEC, NBC and GSC waters cooled to their present level. The intensity of the millennial cyclic variability in terms of temperature increased to its present level.

\subsection{Mechanism of the Long-Term Fluctuation}

As the MYI-covered sea area in the Arctic Ocean decreases, the freezing becomes more effective and DSW formation tends to exceed the amount of the incoming water. There tends to be a constant deficit of incoming water (a downhill situation). The suction and flow of the GSC increase annually.

At a certain point, the Arctic Ocean starts to receive so much warm water that the amount of annually freezing water and the production of the DSW start to decrease. The removal of the DSW does not compensate incoming water, which starts to accumulate. A physical obstacle (an uphill situation) starts to develop. Due to Newton's first law, the incoming water tends to maintain its flow rate. The obstacle grows greater. Finally, the surplus of water in the Arctic Ocean forces the inflow to slow. This is the turning point from the increasing to decreasing flow.

The GSC flow may at first slow considerably in a rather short time span, likely in a few decades. However, in spite of this rapid initial slow-down, the inflow still constantly exceeds the outflow. Increasing ice formation removes some of the excess inflow water. The MYI starts to form. At the same time, DSW production decreases, and constantly removes less water than is supplied. The inflow is forced to constantly decrease.

However, the flow rate of the GSC cannot decrease below the flow volume which is created by the constant thrust of the NEC and NBC flows and the westerlies. When the minimum is achieved, the incoming warm water at first prevents further MYI generation, due to which the DSW formation and outflow start to increase. Inflow starts to increase, the MYI starts melting, and a downhill situation is created. This is the turning point from the decreasing flow rate to an increasing one.

\subsection{Suggestions for Mathematical Modelling of the Holocene Oscillations}

Orbitally induced changes in insolation are due to three astronomical phenomena: (1) the 26,000-year axial precession period (a cycle in which the direction of the Earth's axis of rotation relative to the fixed stars varies); (2) the 41,000-year obliquity period (a cycle in which the angle of the Earth's axial tilt with respect to the orbital plane varies between $22.1^{\circ}$ and $24.5^{\circ}$ ), and (3) the 100,000 -year orbital eccentricity period (the Earth's orbit approximates an ellipse. Eccentricity measures the departure of this ellipse from circularity). These phenomena are suggested to be the major drivers of long-term climate variations in the Earth [98].

It is suggested that the insolation changes by these astronomical parameters would have been dominated the climate oscillations during the Holocene as well. However, modelling efforts for the variability of the Holocene climate have not been successful.

The time span of the Holocene is 12,000 years, meaning that the oscillations have taken place on the scale of millenia. This would have required that frequencies of the 
axial precession and the orbital eccentricity would have temporally intensified as much as 40 to 100 times. In addition, the increase of the summer insolation needed to have selectively targeted small areas in the $\mathrm{NH}$ at one time. This is not possible.

It is evident that the astronomical parameters cannot provide relevant mathematical data for the modelling of the Holocene. The understanding of the major mechanism that give rise to the observed Holocene oscillations has been far from being completely understood.

The major mechanism that gives rise to the observed Holocene oscillations are likely the circulation of the warm and cold waters. It could have been able to influence temperatures in the $\mathrm{NH}$ during the relatively short Holocene era.

During the first two thirds of the Holocene, the most important factors were the advancement of the warm water of the Gulf Stream along its new flow route into the Arctic Ocean, expressed by the melting of the continental ice sheets and the 900-m-thick FIS as well as the salination of the Arctic Ocean water that had been under the FIS.

During the Neoglacial, the flow of the Gulf Stream into the Arctic Ocean has been stabilized. Then the formation of the MYI and its melting in the Arctic Ocean has been the major changing variable. That is why two models are actually needed.

Creating a model that features the actual phenomenon during the Neoglacial period requires data of the long-term flow rate changes of the Gulf Stream into the Arctic Ocean and that of the cold return water (DSW) from there. For this purpose, the amount of the ice formed during the winter in the Arctic Ocean as well as the flow rates of the GSC and NBC need to be measured. In addition, the flow rate changes of the Agulhas eddy should also be measured (see Figure 1 and ref. [90]). This might ultimately show that the Gulf Stream suction likely extends into the Indian Ocean, and via the Indonesian Throughflow (ITF) [99], even to the Pacific Ocean as well.

By studying this process more closely the necessary algorithms for modelling of the Holocene oscillations could be generated. However, many years are likely needed to obtain enough accurate information of the exact flow behavior of ocean currents and their actual impact on climate change, before a precise mathematical model could be generated.

\section{Conclusions}

The temperature in the North Atlantic region during the Holocene has been 5 to $8{ }^{\circ} \mathrm{C}$ higher than it was during the Great Ice Age (GIA). During the Holocene Thermal Maximum (HTM), the temperature was approximately $2^{\circ} \mathrm{C}$ warmer than the overall present temperature. The temporal appearance of the HTM was not synchronous within Europe or across the North Atlantic Ocean.

During the GIA, there was a 900-m-thick floating ice shelf (FIS) in the Arctic Ocean and a smaller FIS in the Baffin Bay and Labrador Sea. The water below the FIS was brackish, and to some depth the top section might have even contained freshwater. The North Sea was covered by grounded ice. Greenland-Scotland Ridge (GSR) and the Grand Banks of Newfoundland (GBN), then an archipelago, were covered by thick ice sheets.

The Gulf Stream Currents (GSC) established ca. 11,700 BP the present flow route via the Straits of Florida into the Arctic Ocean. This was the onset of the Holocene. Atmospheric temperature change could first be detected in Greenland ca. 11,650 BP and then in North England ca. 11,550 BP. According to the sediment accumulation, sea level rise was detectable in the Carioca Basin ca. 11,500 BP.

Around ca. 11,700 BP, the winter ice line retreated maybe in the span of a few decades to follow the FIS line in the Labrador Sea and the ice covered GSR. The formation of the DSW was very low. Outflow took place as surface currents having $\mathrm{T} \approx 0{ }^{\circ} \mathrm{C}$. Since the start of the Neoglacial the outflow has been $\mathrm{T} \approx-2^{\circ} \mathrm{C}$. Due to that the NEC, nSEC, NBC and GSC waters were warmer during the HTM. This is a likely explanation why the overall temperature during the Holocene before the Neoglacial was approximately 2 ${ }^{\circ} \mathrm{C}$ warmer.

Between ca. 11,600 and 10,800 BP the GBN diverted part of the flow of the Gulf Stream also west to southeastern Canada and the New England coast. Flow volume may have been considerable. Then the HTM existed in northeastern America. After 10,800 BP, the Gulf Stream was able to flow over the GBN. Then the flow of the NAC towards Ireland and Scotland increased. The HTM on Aran Island, Ireland started ca. 10,700 BP

By ca. 10,650 BP, Lake Vardfjelltjønna in Norway was deglaciated. Between ca. 10,000 and 8000 BP the coast of Norway diverted the GSC flow south through the English Channel. The water in the Southern Bight was then brackish. In northern and central Europe, the HTM occurred between ca. 9,500 and 7,000 BP. Boreal hazel forests seem to have been especially characteristic of central and western Europe during the HTM.

Between ca. 6000 and 4500 BP was the Mid-Holocene cooling. Salination of the freshwater in the Arctic Ocean areas released from the FIS by the double diffusive convection (DDC) was then proceeding. DSW formation increased gradually and similarly outflow gradually moved from being surface flow to undercurrent flow.

The Neoglacial period began ca. 4,500 BP. By the Arctic Ocean water had obtained normal marine salt content, and DSW formation its present-day level. Outflow from the Arctic Ocean has since taken place, mainly as cold undercurrents.

Intensive (in terms of temperature) millennial-scale cycling of warmer and colder periods began also ca. 4,500 BP. Depending on the amount of insulating MYI, the rate of DSW formation varies. This causes the long-term fluctuation in the flow rate of the GSC. When increasingly 
larger sea areas are covered by MYI, DSW formation decreases while the suction and flow rate of the GSC decrease and vice versa. The amplitude of one cycle is 750 to 800 years.

\section{List of Abbreviations}

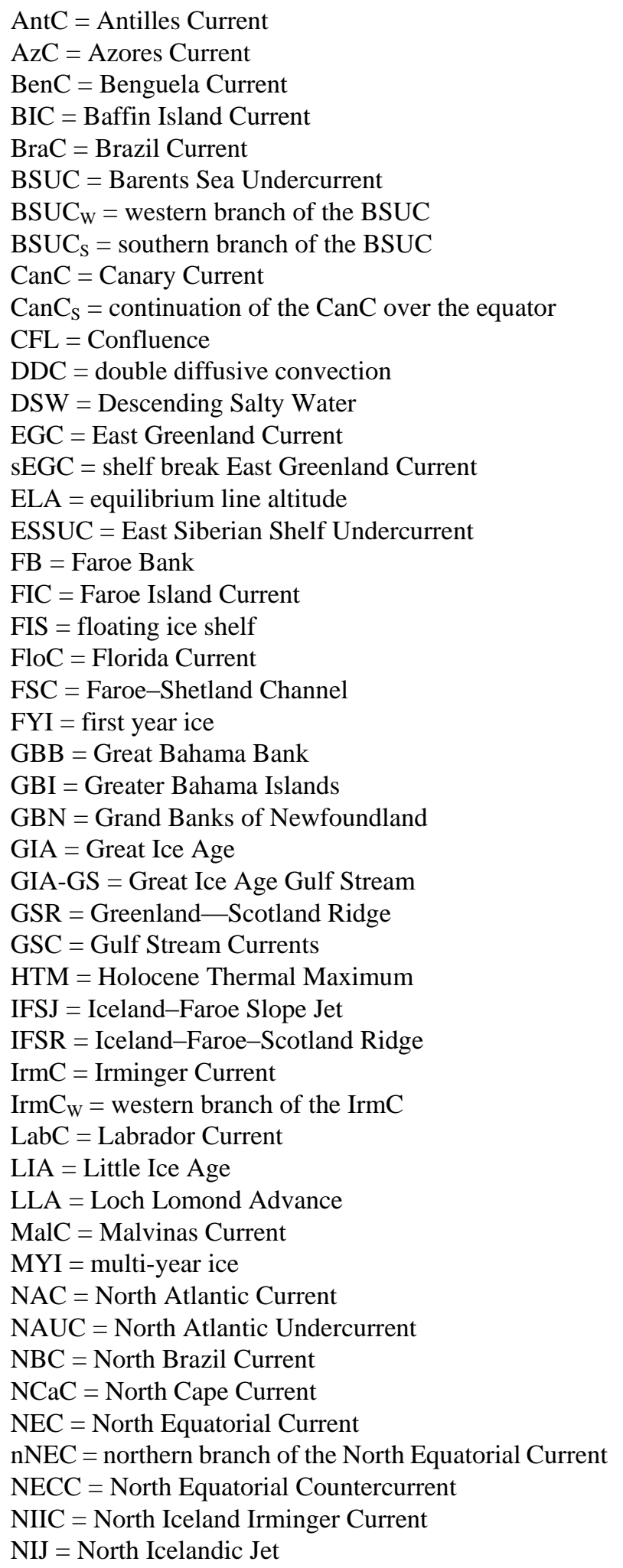

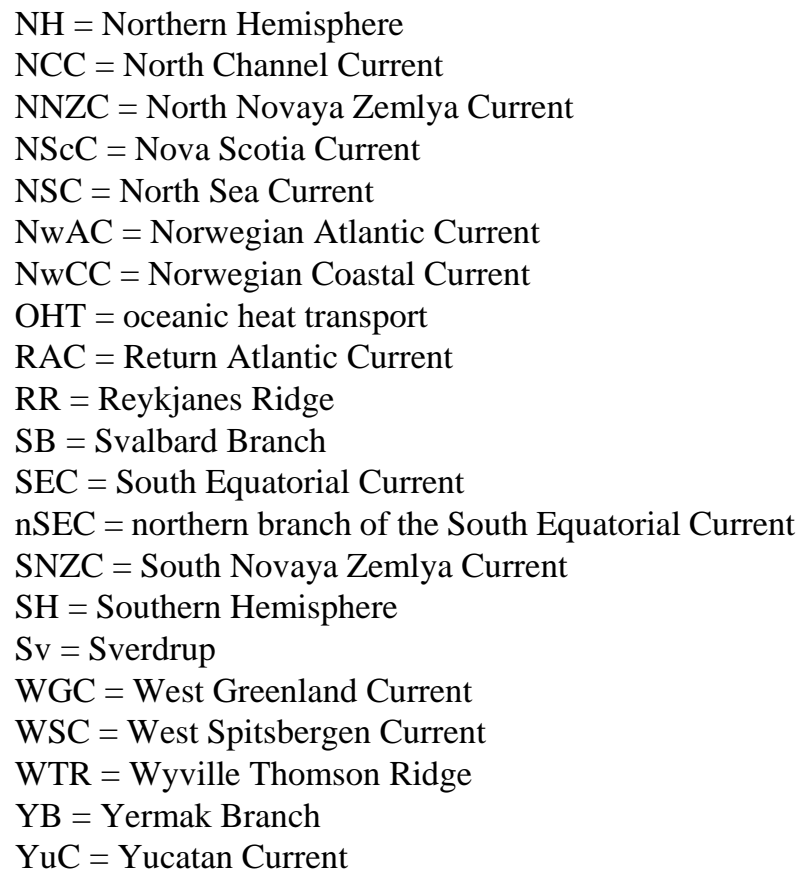

\section{Acknowledgements}

I am very grateful to Matthew Wuethrich from the University of Jyväskylä Language Services for revising the English of the manuscript. I'd like to thank my daughter Heidi for drawing the sea currents in Figures 1-3, as well as my wife Ritva for her help.

\section{REFERENCES}

[1] W. Dansgaard, J. W. C. White, S. J. Johnsen, The abrupt termination of the Younger Dryas climate event, Nature, Vol. 339, No. 6225, 532-534, 1989. DOI: $10.1038 / 339532 \mathrm{a} 0$.

[2] P. Stone, D. Millward, B. Young, J. W. Merritt, S. M. Clarke, M. McCormac, and D. J. D. Lawrence, Holocene, in British regional geology: Northern England. Fifth edition, 2010. British Geological Survey. Keyworth, Nottingham x $+294 \mathrm{pp}$.

[3] B. A. S. Davis, S. Brewer, A. C. Stevenson and J. Guiot, The temperature during the Holocene reconstructed from pollen data, Quaternary Science Reviews, Vol. 22, 17011716, 2003.

[4] G. H. Haug, K. A. Hughen, L. C. Peterson, D. M. Sigman and U. Rohl, Southward migration of the Intertropical Convergence Zone through the Holocene, Science, Vol. 293, No. 5533, 1304-1308, 2001. DOI: 10.1126/science.1 059725 .

[5] K. Molloy and M. O'Connell, Post-glaciation plant colonization of Ireland: fresh insights from An Loch Mór, Inis Oírr, western Ireland, 2014. In: D. P. Sleeman, J. Carlsson and J. E. L. Carlsson, Mind the Gap II: new insights into the Irish postglacial. Irish Naturalists' Journal, Belfast. 
[6] D. Eisma, W. G. Mook and C. Laban, 1981: An early Holocene tidal flat in the Southern Bight. In S.-D. Nio, R. T. E. Schüttenhelm and T. C. E. van Weering (eds.), Holocene Marine Sedimentation in the North Sea Basin. International Association of Sedimentologists, Special Publication 5, 229237, Oxford, Blackwell Scientific, 1981. ISBN $063200858 \mathrm{X}$

[7] W. Karlén and J. A. Matthews, Reconstructing Holocene Glacier Variations from Glacial Lake Sediments: Studies from Nordvestlandet and Jostedalsbreen-Jotunheimen, Southern Norway, Geografiska Annaler, Series A, Physical Geography, Vol. 74, No. 4, 327-348, 1992. doi.org/10.2307/52 1430.

[8] B. V. Odgaard, The Holocene vegetation history of northern West Jutland, Denmark, Opera Botanica, Vol. 123, 1-171, 1994. ISSN 0078-5237.

[9] M. Gałka and K. Toplski, Macrofossil evidence of early Holocene presence of Picea Abies (Norway spruce) in NE Poland, Annales Botanici Fennici, Vol. 50, No. 3, 129-141, 2013. doi.org/10.5735/085.050.0302.

[10] H. Seppä, G. Schurgers, P. A Miller, A. E. Bjune, T. Giesecke, N. Kühl, H. Renssen and J. S. Salonen, Trees tracking a warmer climate: The Holocene range shift of hazel (Corylus avellana) in northern Europe, The Holocene, Vol. 25, No 1, 53-63, 2015. DOI: 10.1177/095968361455 6377.

[11] T. W. Anderson and J. B. Macpherson, Wisconsin Late-glacial environmental change in Newfoundland: a regional review, Journal of Quaternary Science, Vol. 9, 171-178, 1994. doi.org/10.1002/jqs.3390090213.

[12] O.T. Gibb, S. Steinhauer, B. Frechette, A. de Vernal, C. Hillaire-Marcel, Diachronous evolution of sea surface conditions in the Labrador Sea and Baffin Bay since the last deglaciation, Holocene, Vol. 25, 1882-11897, 2015. doi.org/10.1177/0959683615591352.

[13] M. Heikkilä and H. Seppä, A 11,000 yr palaeotemperature reconstruction from the southern boreal zone in Finland, Quaternary Science Review, Vol. 22, 541-554, 2003. DOI: 10.1016/S0277-3791(02)00189-0.

[14] H. Seppä and A. Poska, Holocene annual mean temperature changes in Estonia and their relationship to solar insolation and atmospheric circulation patterns, Quaternary Research Vol. 61, 22-31, 2004. DOI:10.1016/j.yqres.2003.08.005

[15] H. L. Jansen, J. R. Simonsen, S. O. Dahl, J. Bakke, P. R. Nielsen, Holocene glacier and climate fluctuations of the maritime ice cap Høgtuvbreen, northern Norway, The Holocene, 2016, Vol. 26, No. 5, 736-755, 2016. doi.org/10.1177/0959683615618265.

[16] F. C. Ljungqvist, A new reconstruction of temperature variability in the extratropical Northern Hemisphere during the last two millennia. Geografiska Annaler, Vol. 92, No. 3, 339-351, 2010. doi.org/10.1111/j.1468-0459.2010.00399. $\mathrm{x}$.

[17] D. C. Lund, J. Lynch-Stieglitz and W. B. Curry, Gulf Stream density structure and transport during the past millennium, Nature, Vol. 444, No. 7119, 601-604, 2006. DOI: $10.1038 /$ nature 05277 .

[18] R. G. Soutelino, I. C. A. da Silva, A. Gangopadhyay and J. A. Miranda, Is the Brazil Current eddy - dominated to the north of $20^{\circ} \mathrm{S}$ ? Geophysical Research Letters, Vol. 38, No. 3, 2011. http s://doi.org/10.1029/2010GL046276.

[19] S. G. Philander, Atlantic Ocean equatorial currents, Princeton University, pp. 189-190, 2001. Princeton, NJ, USA, Academic Press. DOI: 10.1006/rwos.2001.0361].

[20] W. H. Berger and G. Wefer, Central Themes of South Atlantic Circulation. In G. Wefer, W. H. Berger, G. Siedler and D. J. Web (Eds.), The South Atlantic: Present and Past Circulation, Springer Verlag, Berlin, 1996. ISBN: 978-3-642-80355-09.

[21] W. Geibert, J. Matthiessen, I. Stimac, J. Wollenburg, R. Stein: Glacial episodes of a freshwater Arctic Ocean covered by a thick ice shelf. Nature, Vol. 590, 97-102, 2021. DOI: 10.1038/s41586-021-03186-y.

[22] A. Elverhøi, W. Fjeldskaar, A. Solheim, M. Nyland-Berg and L. Russwurm, The Barents Sea Ice Sheet-A model of its growth and decay during the last ice maximum, Quaternary Science Reviews, Vol. 12, No. 10, 863-873, 1993. DOI.org/10.1016/0277-3791(93)90025-H.

[23] K. Hänninen, The Formation of the Sahara Desert: Evidence for the Slow Ending of the Great Ice Age, Environment and Ecology Research, Vol. 9, No. 2, 76-91, 2021. DOI: 10.13189/eer.2021.090204.

[24] A. J. Gow and W. B. Tucker III, Physical and Dynamic Properties of Sea Ice in the Polar Oceans, U.S. Army Corps of Engineers Cold Regions Research \& Engineering Laboratory, p. 3, 1991. https://pdfs.semanticscholar.org/70 d4/ae2567ad692155fbda4dc3bae377a10f5ce0.pdf.

[25] /www.convertunits.com/from/technical+atmosphere/to/n/ $\mathrm{m} 2$.

[26] G. Hannon, M. Rundgren and C. A. Jessen, Dynamic early Holocene vegetation development on the Faroe Islands inferred from high-resolution plant macrofossil and pollen data, Quaternary Research, Vol. 73, No. 2, 163-172, 2010. DOI: 10.1016/j.yqres.2009.11.003.

[27] K. D. Bennett, J. A. Fossitt, M. J. Sharp and V. R. Switsur, Holocene vegetational and environmental history at Loch Lang, South Uist, Western Isles, Scotland, New Phytol., Vol. 114, No. 2, 281-298, 1990. doi.org/10.1111/j.146 9-8137.1990.tb00400.x.

[28] P. M. Harris, J. Ellis, and S. Purkis, Great Bahama Bank Part I: Evaluating Water-Depth Variation on a "Flat-Topped" Isolated Carbonate Platform, Search and Discovery Article \#50960. Annual Convention and Exhibition, Houston, Texas, April 6-9, 2014, AAPG. www.searchanddiscovery.com/pdfz/documents/2014/5096 Oharris/ndx_harris.pdf.html

[29] D. M. Peteet, R. A. Daniels, L. E. Heusser, J. S. Vogel, J. R. Southon, and D. E. Nelson, Late-glacial pollen, macrofossils and fish remains in Northeastern, USA: The Younger Dryas oscillation, Quaternary Science Review, Vol. 12, 597-612, 1993, DOI: 10.1016/0277-3791(93)900 $02-4$.

[30] Sailing Directions for Newfoundland: Including the Coast of Labrador from Long Point to St Lewis Sound, U. S. Hydrographic Office (H.O.) No. 73, pp. 325-328, US Government Printing Office, Washington 1942, Sixth Edition. 
[31] P. Putnins, The climate of Greenland. In S. Orvig (ed.), Climates of the polar regions, World Survey of Climatology, Vol. 14, 3-128, 1970. Elsevier, Amsterdam.

[32] J. A. Fossitt, Late-Glacial and Holocene Vegetation History of Western Donegal, Ireland, Biology and Environment: Proceedings of the Royal Irish Academy, Vol. 94B, No. 1, 1-31, 1994. www.jstor.org/stable/20499908.

[33] A. G. Smith and I. C. Goddard, A 12 500-year record of vegetational history at Sluggan Bog, Co. Antrim, N. Ireland (incorporating a pollen zone scheme for the non-specialist) New Phytologist Vol. 118, 167-187, 1991. doi.org/10.1111/j.1469-8137.1991.tb00576.x.

[34] A. J. Craig, Pollen Percentage and Influx Analyses in South-East Ireland: A Contribution to the Ecological History of the Late-Glacial Period, Journal of Ecology, Vol. 66, No. 1, 297-324, 1978. doi.org/10.2307/2259194.

[35] J. B. Innes, R. C. Chiverrell, J. J. Blackford, P. J. Davey, S. Gonzalez, M. M. Rutherford and P. R. Tomlinson, Earliest Holocene Vegetation History and Island Biogeography of the Isle of Man, British Isles, Journal of Biogeography, Vo. 31, No. 5, 761 - 772, 2004. www.jstor.org/stable/3554844.

[36] B. Ghilardi and M. O'Connell, Early Holocene vegetation and climate dynamics with particular reference to the $8.2 \mathrm{ka}$ event: pollen and macrofossil evidence from a small lake in western Ireland, Vegetation History and Archaeobotany, Vol. 22, 99-114, 2013. DOI: 10.1007/s00334-012-0367-x.

[37] J. A. Marusek, A Chronological Listing of Early Weather Events, $7^{\text {th }}$ Edition, 2010. chrome-extension://oemmndcbl dboiebfnladdacbdfmadadm/http://www.breadandbutterscie nce.com/Weather.pdf.

[38] A. G. Tansley, The British Islands and Their Vegetation, Vol. 1, Part 2, p. 155, 1965, Cambridge University Press,

[39] M. J. Grant, P. D. M. Hughes and K. E. Barber, Climatic influence upon early to mid-Holocene fire regimes within temperate woodlands: a multi-proxy reconstruction from the New Forest, southern England, Journal of Quaternary Science, Vol. 29, No. 2, 175-188, 2014. DOI: 10.1002/jqs.2692.

[40] M. Tikkanen,and J. Oksanen, Late Weichselian and Holocene shore displacement history of the Baltic Sea in Finland. Fennia Vol. 180, No. 1-2, 9-20, 2002. Helsinki. ISSN 0015-0010.

[41] G. R. M. Bromley, A. E. Putnam, K. M. Rademaker, T. V. Lowell, J. Schaefer, B. Hall, G. Winckler, S. D. Birkel, and H. W. Borns, Younger Dryas deglaciation of Scotland driven by warming summers, PNAS, Vol. 111, No. 17, 6215-6219. https://doi.org/10.1073/pnas.1321122111.

[42] H. J. B Birks, Holocene isochrone maps and patterns of tree-spreading in the British Isles. Journal of Biogeography Vol. 16, No. 6, 503-540, 1989. doi.org/10.2307/2845208.

[43] H. E. Wittmeier, J. Bakke, K. Vasskog, M. Trachseld, Reconstructing Holocene glacier activity at Langfjordjøkelen, Arctic Norway, using multi-proxy fingerprinting of distal glacier-fed lake sediments Quaternary Science Reviews, Vol. 114, 78-99, 2015. doi.org/10.1016/j.quascirev.2015.02.007.

[44] J, Bakke, S. O. Dahl, Ø. Paasche, J. R. Simonsen, B. Kvisvik, K. Bakke and A. Nesje, A complete record of
Holocene glacier variability at Austre Okstindbreen, northern Norway: An integrated approach. Quaternary Science Reviews Vol. 29, No. 9, 1246-1262, 2010. DOI: 10.1016/j.quascirev.2010.02.012.

[45] A. Korhola, Holocene climatic variations in southern Finland reconstructed from peat-initiation data, The Holocene Vol. 5, No. 1, 43-58, 1995. doi.org/10.1177/095 968369500500106.

[46] J. Lundqvist, Kvartärtiden-jordarterna. In M., Lindström, J. Lundqvist and T. Lundqvist (Eds.), Sveriges geologi från urtid tillnutid, Lund: Student Litteratur, 231-372, 1991

[47] H. Seppä and H.J. B. Birks, July mean temperature and annual precipitation trends during the Holocene in the Fennoscandian tree-line area: pollen-based climate reconstructions, The Holocene Vol. 11, No. 5, 527-539, 2001. doi.org/10.1191/095968301680223486.

[48] W. Karlén, Scandinavian glacial climatic fluctuations during the Holocene, Quaternary Science Reviews Vol. 7, 199-209, 1988. doi.org/10.1016/0277-3791(88)90006-6.

[49] M. Eronen and P. Zetterberg, Climatic changes in northern Europe since late glacial times, with special reference to dendroclimatological studies in northern Finnish Lapland, Geophysica, Vol. 32, No. 1-2, 35-60. 1996.

[50] S. Lauterbach, A., Brauer, N. Andersen, D. L. Danielopol, P. Dulski, P. M. Hüls, K. Milecka, T. Namiotko, B. Plessen, U. von Grafenstein and \& DecLakes participants: Multi-proxy evidence for early to mid-Holocene environmental and climatic changes in northeastern Poland. Boreas, Vol. 40, No. 1, 57-72, 2010. DOI: 10.1111/j.1502-3885.2010.0015 9.x.

[51] M. McHenry and P. Dunlop, The subglacial imprint of the last Newfoundland Ice Sheet, Canada, Journal Maps, Vol. 12, No. 3, 462-483, 2016.doi.org/10.1080/17445647.2015. 1044038 .

[52] J. Weiser, J. Titschack, M. Kienast, I. N. McCave, A. A., Lochte, J. Saini and R. Stein, Atlantic water inflow to Labrador Sea and its interaction with ice sheet dynamics during the Holocene, Quaternary Science Reviews, Vol. 256, 106833, 2021. doi.org/10.1016/j.quascirev.2021.1068 33.

[53] W. J. Merryfield, G. Holloway and A. E. Gargett, Differential vertical transport of heat and salt by weak stratified turbulence, Geophysical Research Letters Vol. 25, No. 15, 2773-2776, 1998.

[54] R. W. Schmitt, Double diffusion in oceanography, Annual Review of Fluid Mechanics, Vol. 26, 255-285, 1994. doi.org/10.1146/annurev.fl.26.010194.001351.

[55] M. Jakobsson, K. A. Hogan, L. A. Mayer, A. Mix, A. Jennings, J. Stoner, B. Eriksson, K. Jerram, R. Mohammad, C. Pearce, B. Reilly, and C. Stranne, The Holocene retreat dynamics and stability of Petermann Glacier in northwest Greenland, Nature Communications, Vol. 9, No. 1, 2104, DOI: 10.1038/s41467-018-04573-2, 201.

[56] H. Detlef, B. Reilly, A. Jennings, M. M. Jensen, M. O'Regan, M. Glasius, J. Olsen, M. Jakobsson and C. Pearce, Holocene sea-ice dynamics in Petermann Fjord, The Cryosphere, 15, 4357-4380, 2021. doi.org/10.5194/tc-15-4 357-2021. 
[57] S. Baranowski and W. Karlén, Remnants of Viking Age Tundra in Spitsbergen and Northern Scandinavia, Geografiska Annaler: Series A, Physical Geography, Vol. 58, No. 1 - 2, 35 - 40, 1976. doi.org/10.1080/04353676.19 76.11879922 .

[58] B. Kjøllmoen, L. M. Andreassen, H. Elvehøy, M. Jackson, B. Kjøllmoen and R. H. Giesen, Glacio-logical Investigations in Norway in 2010, The Norwegian Water Resources and Energy Directorate (NVE) 2011. Available at: chrome-extension://oemmndcbldboiebfnladdacbdfmada dm/https://publikasjoner.nve.no/report/2011/report2011_0 3.pdf.

[59] G. Bond, W. Showers, M. Cheseby, R. Lotti, P. Almasi, P. de Menocal, P. Priore, H. Cullen, I. Hajdas, G. Bonani, A Pervasive Millennial-Scale Cycle in North Atlantic Holocene and Glacial Climates, Science, Vol. 278, No. 5341, 1257-1266, 1997. DOI: 10.1126/science.278.5341.1 257.

[60] D. Willard, C. Bernhardt, D. A. Korejwo and S. R. Meyers, Impact of millennial-scale Holocene climate variability on eastern North American terrestrial ecosystems: Pollen-based climatic reconstruction, Global and Planetary Change Vol. 47, No 1, 17-35, 2005. DOI: 10.1016/j.glopla cha.2004.11.017.

[61] Committee on Surface Temperature Reconstructions for the last 2,000 years, Overview, 2006, The National Academic Press, Washington DC, USA. ISBN: 10: 0-309-10225-1. www.nap.edu/read/11676/chapter/3.

[62] B. Fagan, The Little Ice Age, Basic Books, New York 2019. ISBN: 978-1-5416-1859-6.

[63] en.wikipedia.org/wiki/Great_Frost_of_1709.

[64] J. Luterbacher, D. Dietrich, E. Xoplaki, M. Grosjean and H. Wanner, European Seasonal and Annual Temperature Variability, Trends, and Extremes Since 1500, Science, Vol. 303, No. 5663, 1499-1503, 2004. DOI:10.1126/science.10 93877.

[65] E. I. Kouri and J. E. Olesen (Eds.), The Cambridge History of Scandinavia, Volume II 1520-1870, pp. 133-210, 2016. Published online by Cambridge University Press. DOI: https://doi.org/10.1017/CHO9781139031639 [Opens in a new window].

[66] P. G. M., N. Kula and M. H. Ribergaard, Irminger Water variability in the West Greenland Current, Geophysical Research Letters, Vol. 34, L17601, 2007. DOI: 10.1029/2007GL030419.

[67] A. Sarafanov, A. Falina, H. Mercier, A. Sokov, P. Lherminier, C. Gourcuff, S. Gladyshev, F. Gaillard and N. Daniault, Mean full-depth summer circulation and transports at the northern periphery of the Atlantic Ocean in the 2000s, Journal of Geophysical Research, Vol. 117, C01014, 2012. DOI: 10.1029/2011JC007572.

[68] H. Valdimarsson and S-A. Malmberg, Near-surface circulation in Icelandic waters derived from satellite tracked drifters, Rit Fiskideildar Vol. 16 23-39, 1999.

[69] K. A. Orvik, Ø. Skagseth and M. Mork, Atlantic inflow to the Nordic Seas: Current structure and volume fluxes from moored current meters, M-ADCP and SeaSoar-CTD observations 1995-1999, Deep Sea Research, Part I, Vol. 48, 937-957, 2001. DOI: 10.1016/S0967-0637(00)00038-.
[70] R. B. Ingvaldsen, Width of the North Cape Current and location of the Polar Front in the western Barents Sea, Geophysical Research Letter, Vol. 32, L16603 2005, DOI:10.1029/2005GL023440.

[71] Ø. Skagseth, T. Furevik, R. Ingvaldsen, H. Loeng, K. A. Mork, K. A. Orvik and V. Ozhigin, Volume and heat transports to the Arctic Ocean via the Norwegian and Barents Seas, pp. 45-64, 2008. In: R. Dickson, J. Meincke and P. Rhines (Eds.), Arctic-Subarctic Ocean fluxes: Defining the role of the Northern Seas in Climate. Springer, Netherlands. ISBN: 978-1-4020-6773-0.

[72] Temperature and salinity in the Fram Strait, www.mosj.no/en/climate/ocean/temperature-salinity-framstrait.html.

[73] Z. Hofmann, W.-J. von Appen and C. Wekerle, Seasonal and mesoscale variability of the two Atlantic Water recirculation pathways in Fram Strait. Journal of Geophysical Research: Oceans, Vol. 126, No. 7, e2020JC017057, 2021. doi.org/10.1029/2020JC017057.

[74] Sea Currents along the NSR, State hydrographic department of the Ministry of Transport of Russian Federation, 1996. In ARCTIS Database, Arctic Resources and Transportation Information System.

[75] K. H. Christensen, A. K. Sperrevik and G. Broström, On the Variability in the Onset of the Norwegian Coastal Current, Journal of Physical Oceanography, Vol. 48, No. 3, 723-738, 2018. DOI: https://doi.org/10.1175/JPO-D-17-0117.1.

[76] Ø. Skagseth, K. F. Drinkwater and E. Terrile, Wind- and buoyancy-induced transport of the Norwegian Coastal Current in the Barents Sea, Journal of Geophysical Research. Oceans, Vol. 116, C08007, 2011. https://doi.org/10.1029/2011JC006996.

[77] K. I. Ohshima, Y. Fukamachi, G. D. Williams, S. Nihashi, F. Roquet,Y. Kitade, T. Tamura, D. Hirano, L. Herraiz-Borreguero, I. Field, M. Hindell, S. Aoki and M. Wakatsuchi, The Antarctic Bottom Water production by intense sea-ice formation in the Cape Darnley polynya, Nature Geoscience, Vol. 6, 235-240, 2013. DOI: 10.1038/ngeo 1738 .

[78] www.britannica.com/science/bottom-water.

[79] R. Kwok, Arctic sea ice thickness, volume, and multiyear ice coverage: losses and coupled variability (1958-2018) Environmental Research Letters, Vol. 13, No. 10, 105005, 2018. doi.org/10.1088/1748-9326/aae3ec.

[80] R. Lindsay and A. Schweiger, Arctic sea ice thickness loss determined using subsurface, aircraft, and satellite observations. The Cryosphere, Vol 9, No. 1, 269-283, 2015. DOI: $10.5194 /$ tc-9 -269-2015,

[81] A. A. Petty, M. M. Holland, D. A. Bailey, N. T. Kurtz, Warm Arctic, Increased Winter Sea Ice Growth? Geophysical Research Letters, Vol. 45, No. 23, 12,92212,930, 2018. doi.org/10.1029/2018GL079223.

[82] A. Ganachaud and C. Wunsch, Improved estimates of global ocean circulation, heat transport and mixing from hydrographic data, Nature Vol. 408, 453-457, 2000.

[83] J. R. N. Lazier and D.G. Wright, Annual Velocity variations in the Labrador Current, Journal of Physical Oceanography, 
Vol. 23, 659-678, 1993.doi.org/10.1175/1520-0485(1993) 023<0659:AVVITL>2.0.CO;2.

[84] E. Navarro-Pérez and E. D. Barton, Seasonal and interannual variability of the Canary Current. Scientia Marina, Vol. 65, No. S1, 205-213, 2001. DOI: 10.3989/scimar.2001.65s 1205 .

[85] M. A. Charette, L. E. Kipp, L. T. Jensen, J. S. Dabrowski, L. M. Whitmore, J. N. Fitzsimmons, T. Williford, A. Ulfsbo, E. Jones et al. (2020). The Transpolar Drift as a source of riverine and shelf-derived trace elements to the central Arctic Ocean. Journal of Geophysical Research: Oceans, 125, e2019JC015920. doi.org/10.1029/2019JC015920.

[86] J. Uotila and J. Launiainen and T. Vihma, An Analysis of Buoy Drift in the Northern Atlantic with Detection of Drogue Loss Events, Atmosphere-Ocean, Vol. 35, No. 4, 471-494, 1997.

[87] L. Beaird, P. B. Rhines and C. C. Eriksen, Overflow Waters at the Iceland-Faroe Ridge Observed in Multiyear Sea-glider Surveys, Journal of Physical Oceanography, Vol. 43, No. 11, 2334-2351, 2013. doi.org/10.1175/JPO-D-13029.1 .

[88] T. J. Sherwin and W. R. Turrell, Mixing and advection of a cold water cascade over the Wyville Thomson Ridge, Deep-Sea Research Part I: Oceanographic Research Papers. Vol 52, No. 8, 1392-1413, 2005. DOI: 10.1016/j.dsr.2005.03.002.

[89] D. Ledu, A. Rochon, A. de Vernal and G. St-Onge, Palynological evidence of Holocene climate change in the eastern Arctic: a possible shift int he Arctic oscillation at the millennial time scale, Canadian Journal of Earth Science, Vol. 45, 1363-1375, 2008. DOI: 10.1139/E08-043.

[90] S. Jonsson and H. Valdmarsson, A new path for the Denmark Strait overflow water from the Iceland Sea to Denmark Strait, Geophysical Research Letters, Vol. 31, No. 3, L03305, 2004. DOI: 10.1029/2003GL019214.

[91] Kari Hänninen, Driving Forces and Flow Mechanisms of the Atlantic Ocean Currents Environment and
Ecology Research, Vol. 8, No. 1, 1-28, 2020. DOI: 10.13189/eer.2020.080101.

[92] S. Semper, R.S. Pickart, K. Våge, K. M. H. Larsen, H. Hátún and B. Hansen, The Iceland-Faroe Slope Jet: a conduit for dense water toward the Faroe Bank Channel overflow. Nature Communications, Vol. 11, No. 1, 5390, 2020. DOI: $10.1038 / \mathrm{s} 41467-020-19049-5$

[93] L. Stramma and G. Siedler, Seasonal Changes in the North Atlantic Subtropical Gyre, Journal of Geophysical Research, Vol. 93, No. C7, 8111-8118, 1988. DOI: 10.1029/JC093iC07p08111.

[94] C. Guiavarc'h, A. M. Treguier and A. Vangriesheim, Deep currents in the Gulf of Guinea: along slope propagation of intraseasonal waves, Ocean Science, Vol. 5, 141-153, 2009. doi.org/10.5194/os-5-141-2009.

[95] C. Andersen, N. Koç and M. Moros, A highly unstable Holocene climate in the subpolar North Atlantic: evidence from diatoms, Quaternary Science Reviews, Vol. 23, No. 20-22, 2155-2166, 2004. doi.org/10.1016/j.quascirev.200 4.08.004.

[96] L. Aario, Über die Wald- und Klimaentwicklung an der Lappländischen Eismeerküste in Petsamo. Annales Botanici Societatis Zoologicæ Botanicæ Fennicæ Vanamo, Vol. 19, 1-158, 1943.

[97] W. R. Gehrels, K. Szkornika J. Bartholdy, J. R. Kirby, S. L. Bradley, W. A. Marshall, J. Heinemeier and J. B. T. Pedersen, Late Holocene sea-level changes and isostasy in western Denmark, Quaternary Research, Vol. 66, No. 2, 288-302, 2006. doi.org/10.1016/j.yqres.2006.05.004.

[98] W. Schwarzacher, Cyclostratigraphy and the Milankovitch Theory, Developments in Sedimentology 52, 1993, Elsevier, Amsterdam. ISBN 0-444-89623-6..

[99] M. C. Wattimena, A. S. Atmadipoera, M. Purba, I. W. Nurjaya and F. Syamsudin, Indonesian Throughflow (ITF) variability in Halmahera Sea and its coherency with New Guinea Coastal Current, IOP Conf. Series: Earth and Environmental Science Vol. 176, No. 1, 012 011, 2018. DOI: $10.1088 / 1755-1315 / 176 / 1 / 012011$ 